\title{
ARID1A Mutations and PI3K/AKT Pathway Alterations in Endometriosis and Endometriosis-Associated Ovarian Carcinomas
}

\author{
Eleftherios P. Samartzis ${ }^{1}$, Aurelia Noske ${ }^{2}$, Konstantin J. Dedes ${ }^{1}$, Daniel Fink ${ }^{1}$ and \\ Patrick Imesch ${ }^{1, *}$
}

1 Division of Gynecology, University Hospital Zurich, Frauenklinikstrasse 10, Zurich CH-8091, Switzerland; E-Mails: eleftherios.samartzis@usz.ch (E.P.S.); konstantin.dedes@usz.ch (K.J.D.); daniel.fink@usz.ch (D.F.)

2 Institute of Surgical Pathology, University Hospital Zurich, Schmelzbergstrasse 12, Zurich CH-8091, Switzerland; E-Mail: aurelia.noske@usz.ch

* Author to whom correspondence should be addressed; E-Mail: patrick.imesch@usz.ch; Tel.: +41-44-255-52-00; Fax: +41-44-255-44-33.

Received: 5 August 2013; in revised form: 26 August 2013 / Accepted: 27 August 2013 / Published: 12 September 2013

\begin{abstract}
Endometriosis is a common gynecological disease affecting $6 \%-10 \%$ of women of reproductive age and is characterized by the presence of endometrial-like tissue in localizations outside of the uterine cavity as, e.g., endometriotic ovarian cysts. Mainly, two epithelial ovarian carcinoma subtypes, the ovarian clear cell carcinomas (OCCC) and the endometrioid ovarian carcinomas (EnOC), have been molecularly and epidemiologically linked to endometriosis. Mutations in the gene encoding the AT-rich interacting domain containing protein 1A (ARIDIA) have been found to occur in high frequency in OCCC and EnOC. The majority of these mutations lead to a loss of expression of the ARID1A protein, which is a subunit of the SWI/SNF chromatin remodeling complex and considered as a bona fide tumor suppressor. ARIDIA mutations frequently co-occur with mutations, leading to an activation of the phosphatidylinositol 3-kinase (PI3K)/AKT pathway, such as mutations in PIK3CA encoding the catalytic subunit, p110 , of PI3K. In combination with recent functional observations, these findings strongly suggest cooperating mechanisms between the two pathways. The occurrence of ARIDIA mutations and alterations in the $\mathrm{PI} 3 \mathrm{~K} / \mathrm{AKT}$ pathway in endometriosis and endometriosis-associated ovarian carcinomas, as well as the possible functional and clinical implications are discussed in this review.
\end{abstract}


Keywords: endometriosis; ovarian clear cell carcinoma (OCCC); endometrioid ovarian carcinoma (EnOC); ARID1A; PI3K/AKT pathway; PIK3CA

\section{Introduction}

The identification of recurrent somatic mutations in endometriosis-associated ovarian cancer, in particular, AT-rich interacting domain containing protein 1A (ARID1A) mutations [1,2], provided the first molecular evidence of a direct pathogenic link between endometriosis and certain subtypes of ovarian carcinomas $[3,4]$.

Endometriosis is a common gynecological inflammatory disease that affects at least $6 \%-10 \%$ of women of reproductive age and is characterized by the presence of endometrial-like tissue outside of the uterine cavity $[5,6]$. The prevalence of this disease is higher in women with abdominal pain, infertility or both, where it rises to an incidence rate of 35\%-50\% [7]. The ectopic endometrial-like tissue is most often found in the pelvic peritoneum, the ovaries and/or the rectovaginal septum, but can also involve uncommon localizations, such as the diaphragm, pleura, pericardium or, even, brain $[7,8]$. The exact pathogenesis of endometriosis has as yet not been fully elucidated. One of the most widely accepted theories is the retrograde menstruation of fragments of menstrual endometrium through the fallopian tubes that may explain the more frequent cases of peritoneal and ovarian endometriosis [5]. The typical clinical symptoms of the disease consist of dysmenorrhea, dyspareunia and infertility. Current treatment options are the surgical removal of endometriotic implants and hormonal suppressant drugs [8]. The overall risk of ovarian cancer associated with endometriosis can be regarded as generally very low [9], but is still increased compared to women not presenting with endometriosis [8].

Clinical suggestion for a causal relationship between endometriosis and ovarian cancer is not novel, and the possible pathogenic link had already been described at the beginning of the $20^{\text {th }}$ century by Sampson [10]. However, larger epidemiological studies showing evidence for a causal relationship between endometriosis and ovarian cancer were lacking until the end of the $20^{\text {th }}$ century [11].

In a large registry study among 20,686 women in Sweden who had been hospitalized for endometriosis, a significantly increased risk for ovarian cancer (standardized incidence ratio (SIR) 1.9, 95\% confidence interval (CI) 1.3-2.8) was found after a mean of 11.4 years of follow-up. The risk of ovarian cancer was increased 2.5-fold in women with a follow-up of more than 10 years [12]. A larger Swedish register study involving 64,492 women with endometriosis confirmed an elevated risk of ovarian cancer in these patients with an SIR of 1.43 (95\% CI 1.19-1.71). The risk of ovarian cancer was considerably higher in patients with early diagnosed and long-standing endometriosis (SIR 2.01 and 2.23, respectively) [13]. Several other studies have also described an increased risk of ovarian cancer in women with endometriosis [14-24]. A large epidemiological pooled analysis of 13 case-control studies, including 13,226 controls and 7911 women with invasive ovarian cancer, investigated the frequency of self-reported endometriosis and found significantly increased risks for ovarian cancer in women with history of endometriosis with an odds ratio of 1.46 (95\% CI 1.31-1.63, $p<0.0001)$ after stratifying for age, ethnic origin and adjustment for the duration of oral contraceptive 
use and parity. Importantly, a significant association of the histological subtypes of clear-cell (OR 3.05, 95\% CI 2.43-3.84, $p<0.0001$ ), endometrioid (OR 2.04, 95\% CI 1.67-2.48, $p<0.0001$ ), and low-grade serous ovarian carcinomas (OR 2.11, 95\% CI 1.39-3.20, $p<0.0001$ ) was found with endometriosis in this study. In contrast, there was no association of endometriosis with mucinous and high-grade serous cancer, as well as borderline tumors [25].

Ovarian cancer is the most lethal gynecological neoplasm and a very heterogeneous disease [26]. Based on extensive morphologic, immunohistochemical and molecular genetic analyses of different epithelial ovarian cancer subtypes, Kurman and Shih proposed that epithelial ovarian carcinomas can be divided in two groups: Type I ovarian carcinomas comprise clear cell carcinomas (OCCC), low-grade endometrioid carcinomas (EnOC), mucinous carcinomas and low-grade serous carcinomas. They tend to be rather slow-growing, low-grade neoplasms and often develop in a stepwise manner from visible precursor lesions. On a molecular level, they often share mutations in different genes, such as KRAS, BRAF, PTEN, PIK3CA, ARID1A, ERBB2, CTNNB1 and PPP2R1A. Type II ovarian carcinomas mainly cover high-grade serous carcinomas and are more frequent, as they represent approximately $75 \%$ of all ovarian carcinomas. These tumors are characterized by aggressive behavior, nearly ubiquitous presence of TP53 mutations and a high level of genetic instability, in contrast to type I tumors, which rarely show TP53 mutations [27-31].

There is growing evidence that epithelial ovarian carcinomas, unlike ovarian germline tumors, may often find their origin in non-ovarian tissue $[32,33]$. This is a shift of paradigms, since until recently, the largely accepted theory was that ovarian epithelial tumors arise from the single cell layer lining the ovarian surface, usually referred to as surface epithelium [34,35]. Hence, numerous molecular studies indicate that the precursor of serous ovarian carcinomas may be localized in the epithelium of the fallopian tubes in the form of a precursor lesion, called serous tubal intraepithelial carcinoma [27,32,36-42]. Epidemiologic data are supporting this theory, since it has been reported that the risk of ovarian cancer decreases after tubal ligation or excision [43-46].

Two distinct histological subtypes of ovarian carcinomas, the OCCC and EnOC, have been directly associated with endometriosis through observational epidemiological studies [14,24,25,47-49]. Atypical endometriosis has long been proposed as the histological precursor lesion of OCCC and EnOC [50,51]. A direct pathogenic link of endometriosis with OCCC and EnOC has been evidenced by the important study of Wiegand et al. demonstrating common truncating mutations and loss of protein expression of the ARIDIA tumor suppressor gene in OCCC and contiguous atypical endometriosis [1]. Whole-exome sequencing performed independently by Jones et al. in eight OCCC confirmed frequent mutations of ARIDIA, as well as PIK3CA, PP2RIA and KRAS. Validation of these results in 42 OCCC (the eight tumors of the discovery cohort and an additional 34 OCCC samples as a validation cohort) by Sanger sequencing reported the frequencies of these mutations at $57 \%, 40 \%$, $7.1 \%$ and $4.7 \%$, respectively [2].

OCCC is the second most common epithelial ovarian cancer subtype, and its prevalence has been shown to differ significantly between geographic regions [52]. The highest prevalence is described in Asian countries, especially in Japan, where it accounts for $15 \%-25 \%$ of epithelial ovarian cancer $[53,54]$. The prevalence in Europe and North America is significantly lower, where it accounts for $1 \%-13 \%$ of ovarian epithelial tumors [55-58]. Interestingly, the prevalence of endometriosis has also been reported to be higher in Asian women in some studies [59]. OCCC are reported to occur at 
an earlier age than serous ovarian cancer, with a median age at diagnosis of 55 years compared to 64 years [58]. Although low-stage OCCC have a relatively good prognosis, high-stage OCCC have a poorer prognosis than stage-matched high-grade serous ovarian carcinomas and are often characterized by resistance to standard carboplatin paclitaxel chemotherapy [53,54,60-64]. Interestingly, OCCC are associated with a 2.5 -fold higher incidence of clinically significant venous thromboembolism than in women with other histological types of epithelial ovarian cancer [65].

The prevalence of EnOC is estimated to be somewhat lower than in OCCC and accounts for $7 \%-13 \%$ of epithelial ovarian cancer $[56,66,67]$. There is an association of endometrioid ovarian carcinomas with uterine endometrial carcinomas in 15\%-20\% of cases [68-72]. Similarly to OCCC, EnOC are often diagnosed as early-stage disease in younger women (median age 47 years) in comparison with serous ovarian cancer and, often, become manifest with pelvic pain, a palpable abdominal mass, abnormal vaginal bleeding and/or newly developed or increased dysmenorrhea and dyspareunia [48,73].

Finally, seromucinous borderline tumors have also been associated with endometriosis. They are a rare subtype of mucinous borderline tumors and show a distinct non-gastrointestinal-type pattern [67]. These tumors coexist with endometriosis in 30\%-70\% and are likely to originate from endometriotic cysts [67,74-76].

This review focuses on common genetic alterations in endometriosis and the endometriosis-associated OCCC and EnOC, with special emphasis on ARIDIA mutations and alterations in the PI3K/AKT pathway and potential cooperative mechanisms between these pathways.

\section{ARID1A Mutations}

\subsection{Background}

The ARIDIA gene encodes the AT-rich interacting domain containing protein 1A (ARIDIA), also known inter alia as BAF250a or p270, which is part of a family of 15 proteins in humans that all contain a characteristic 100-amino acid DNA-binding ARID domain that binds in a sequence non-specific manner to DNA [77]. The ARID1 subfamily is a member of seven ARID subfamilies based on degree of homology of the ARID domain and the similarity between the highly variable non-ARID domain structures [78]. ARIDIA and ARIDIB are the only ARID1 subfamily members and are two mutually exclusive subunits of the SWI/SNF chromatin remodeling complex [79]. It is through this complex that ARID1A probably exerts its role as a tumor suppressor [80]. ARIDIA is located at 1p36.11 [81] and encodes a large protein of approximately $250 \mathrm{kD}$ that is expressed primarily (maybe exclusively) in the nucleus [77]. Its expression is cell-cycle dependent and is higher in the $\mathrm{G}_{0} / \mathrm{G}_{1}$-phase compared to the $\mathrm{S}-$ and $\mathrm{G}_{2} / \mathrm{M}$-phases [82]. ARIDIA encodes two protein isoforms (2285 and 2086 amino acids), but there is no actual knowledge about a functional difference of the two isoforms. It has been described that ARID1A is post-translationally modified through lysine acetylation and serine/threonine phosphorylation, which may potentially regulate protein expression or protein-protein interactions [77,83]. Although its role as a part of the SWI/SNF complex is the best studied interaction of the ARID1A protein, several other protein-protein interactions, such as interactions with p53 [84], with SMAD3 [84], with hormonal receptors, such as the glucocorticoid receptor [85], and others have 
been described. Due to its various interactions, the understanding about the functional effects of ARIDIA mutations remains quite poor and may vary depending on different cell types. Other components of the ATP-dependent SWI/SNF chromatin remodeling complex, such as SMARCB1, have been found to be mutated in a wide variety of cancers [77]. The frequency of mutations of the different components of the SWI/SNF complex typically differs among different cancers [86].

Mutations in the ARIDIA gene occur in a wide variety of different cancers. They have been found to be the most frequent in OCCC, followed by EnOC, but occur ubiquitously in various cancers [86]. Frequent mutations or loss of expression of ARIDIA have also been found in endometrial carcinomas of endometrioid (loss of expression in 29\%), clear cell (loss of expression in 26\%) and serous histology (loss of expression in 18\%) [87,88], pancreatic (mutations in 8\%-45\%) $[89,90]$ and gastric adenocarcinomas (mutations in 8\%-29\%) [91-93], as well as in hepatocellular (mutations in 10\%-17\%) [94-96] and breast carcinomas (mutations in 4\%-35\%) [97,98].

\subsection{ARID1A Mutations in Endometriosis-Associated Ovarian Carcinomas}

A high frequency of $A R I D 1 A$ mutations has been detected in endometriosis-associated ovarian carcinomas. Studies undertaken by Wiegand et al. [1] and by Jones et al. [2] have reported ARIDIA mutations in $46 \%-57 \%$ of OCCC and in $30 \%$ of EnOC. In the study of Wiegand et al., validated RNA-sequencing results of 19 OCCC samples (18 solid OCCC tumor samples and one OCCC cell line (TOV21G)) reported three somatic nonsense mutations, two somatic insertion/deletion mutations, one somatic missense mutation (found simultaneously in a sample containing an insertion mutation) and one gene rearrangement of $A R I D 1 A$ with the neighboring gene, ZDHHC18, with the fusion ends mapping to a homozygous deletion involving most of ARIDIA. These data were verified in a mutation-validation cohort of 210 samples of ovarian carcinomas, including 101 OCCC, 33 EnOC and 76 high-grade serous ovarian carcinomas, as well as a second OCCC cell line (ES2) (cf. Table 1). All the 65 truncating ARIDIA mutations that were found in 47 OCCC and 8 EnOC samples were somatic.

ARIDIA is a large gene containing 20 exons, and the mutations found by Wiegand et al. were distributed evenly across the whole gene, with just a few recurrent mutations between different tumors. Most of the detected mutations were truncating (nonsense or frameshift) and correlated strongly with a loss of ARID1A protein expression in the immunohistochemistry (IHC). A total of 27 (73\%) of the 37 OCCC and five (50\%) of 10 EnOC samples with ARIDIA mutations showed loss of protein expression in IHC, whereas four (11\%) of 36 OCCC and two (9\%) of 23 EnOC samples without ARIDIA mutations were negative for ARID1A protein expression. Since data from exon resequencing and RNA sequencing presented excellent correlation, there was no suggestion for a relevant epigenetic silencing of ARIDIA [1].

It is interesting that only approximately $30 \%$ of the OCCC showed homozygous mutations of ARIDIA, whereas $73 \%$ of heterozygous mutated tumors showed a loss of protein expression without loss of heterozygosity. Similar observations in other cancer types, as well as results of in vitro studies, therefore, suggest a haploinsufficient tumor suppressor role for ARIDIA [1,77].

Jones et al. described 32 mutations in $A R I D I A$ that were also distributed throughout the coding region of $A R I D I A$ and were all predicted to truncate the protein (nine nonsense and 23 
insertion/deletion mutations). Both $A R I D I A$ alleles were affected through loss of heterozygosity or through biallelic mutations in 10 of the 24 tumors harboring ARIDIA mutations [2].

The frequency of loss of ARID1A protein expression in OCCC and EnOC was verified in multiple studies [99-104] and found to be consistent with the initial observations [1,2]. Due to the high frequency of their occurrence, mutations of $A R I D I A$ are regarded to be one of the major genetic alterations in endometriosis-associated OCCC and EnOC [67].

An overview of the studies that analyzed ARID1A expression in ovarian cancer by mutational analysis and/or immunohistochemistry is given in Table 1 .

Table 1. Studies that investigated AT-rich interacting domain containing protein $1 \mathrm{~A}$ $(A R I D 1 A)$ mutations and protein expression in ovarian cancer with sequencing methods and by immunohistochemistry (IHC). OCCC, ovarian clear cell carcinomas; EnOC, endometrioid ovarian carcinomas.

\begin{tabular}{|c|c|c|c|c|}
\hline $\begin{array}{c}\text { Authors, year of } \\
\text { publication }\end{array}$ & Ovarian carcinoma subtypes & Loss of ARID1A protein expression & $\begin{array}{c}\text { ARID1A mutations by sequencing } \\
\text { methods }\end{array}$ & Ref. \\
\hline Jones et al., 2010 & 42 OCCC & - & $\begin{array}{l}57 \% \text { somatic } A R I D 1 A \text { mutations in a total } \\
\text { of } 42 \text { OCCC }\end{array}$ & {$[2]$} \\
\hline $\begin{array}{l}\text { Wiegand et al., } \\
\qquad 2010\end{array}$ & $\begin{array}{l}18 \text { OCCC tumor samples and } 1 \\
\text { OCCC cell line (whole } \\
\text { transcriptome) - discovery cohort } \\
210 \text { ovarian carcinomas and a } \\
\text { second OCCC cell line } \\
\text { (ARIDIA sequencing); } \\
\text { mutation validation cohort } \\
455 \text { ovarian carcinomas } \\
\text { (IHC validation cohort) }\end{array}$ & $\begin{array}{l}\text { Loss of ARID1A protein expression } \\
\text { in } 55(42 \%) \text { of } 132 \text { OCCC, } 39(31 \%) \\
\text { of } 125 \text { EnOC, and } 12(6 \%) \text { of } 198 \\
\text { high-grade serous ovarian carcinomas. }\end{array}$ & $\begin{array}{l}\text { Somatic } A R I D 1 A \text { mutations ( } 3 \text { nonsense, } \\
2 \text { insertion/deletion, } 1 \text { missense and } 1 \text { gene } \\
\text { rearrangement) in the discovery cohort } \\
\text { ARIDIA mutations in } 55 \text { of } 119 \text { OCCC } \\
(46 \%), 10 \text { of } 33 \text { EnOC ( } 30 \%) \text { and none of } \\
\text { the } 76 \text { high-grade serous } \\
\text { ovarian carcinomas }\end{array}$ & {$[1]$} \\
\hline $\begin{array}{l}\text { Maeda et al., } \\
2010\end{array}$ & OCCC & $\begin{array}{l}\text { Negative ARID1A expression in } 88 \text { of } \\
149(59 \%) \text { OCCC tumor samples } \\
\text { by IHC }\end{array}$ & $\begin{array}{l}\text { Sequencing of } 12 \text { OCCC tumor samples; } \\
9 \text { samples with } A R I D 1 A \text { mutations and } \\
3 \text { with wild-type expression }\end{array}$ & [99] \\
\hline Guan et al., 2011 & serous and mucinous $\mathrm{OC}$ & $\begin{array}{l}\text { No loss of ARID1A expression in } 221 \\
\text { high-grade serous, } 15 \text { low-grade serous, } \\
\text { and } 36 \text { mucinous ovarian carcinomas }\end{array}$ & $\begin{array}{l}\text { No } A R I D 1 A \text { mutations detected in } 32 \\
\text { high-grade serous, } 19 \text { low-grade serous and } \\
5 \text { mucinous ovarian carcinomas }\end{array}$ & [88] \\
\hline $\begin{array}{l}\text { Katagiri et al., } \\
2011\end{array}$ & $\mathrm{OCCC}$ & $\begin{array}{l}\text { Loss of ARID1A expression in } 9 \\
(15 \%) \text { of } 60 \text { OCCC }\end{array}$ & - & {$[100]$} \\
\hline $\begin{array}{l}\text { Yamamoto et al., } \\
2012\end{array}$ & $\begin{array}{l}90 \text { cases of primary OCCC } \\
\text { (including } 42 \\
\text { previously examined) }\end{array}$ & $\begin{array}{l}\text { Loss of ARID1A expression in } 44 \% \\
\text { of } 90 \text { OCCC samples }\end{array}$ & - & {$[102]$} \\
\hline $\begin{array}{l}\text { Lowery et al., } \\
\qquad 2012\end{array}$ & 212 OCCC and EnOC & $\begin{array}{l}\text { Loss of ARID1A expression in } 34(41 \%) \\
\text { of } 82 \text { OCCC and } 62(48 \%) \text { of } 130 \text { EnOC }\end{array}$ & - & {$[103]$} \\
\hline $\begin{array}{l}\text { Samartzis et al., } \\
2012\end{array}$ & $\begin{array}{l}136 \text { ovarian cancer samples as } \\
\text { study control ( } 23 \text { OCCC, } \\
28 \text { EnOC, } 63 \text { serous ovarian } \\
\text { carcinomas, } 15 \text { mucinous } \\
\text { ovarian carcinomas) }\end{array}$ & $\begin{array}{l}\text { Loss of ARID1A expression in } 5 \\
(22 \%) \text { of } 23 \text { OCCC, } 13(46 \%) \text { of } 28 \\
\text { EnOC, } 7(11 \%) \text { of } 63 \text { serous ovarian } \\
\text { carcinomas, } 4(27 \%) \text { of } 15 \text { mucinous } \\
\text { ovarian carcinomas }\end{array}$ & - & {$[104]$} \\
\hline
\end{tabular}




\subsection{Loss of ARID1A Expression in Endometriosis}

Mutations of ARIDIA have been demonstrated in atypical endometriosis that, in contrast to the adjacent OCCC tissue, was negative for HNF-1 $\beta$ and retained estrogen receptor expression. This indicates that $A R I D I A$ mutations are an early event in the pathogenesis of endometriosis-associated ovarian carcinomas. In contrast to tumor-adjacent atypical endometriosis, no mutations or loss of ARID1A expression were found in the distal non-atypical endometriotic tissue of the same patients [1].

Table 2. Studies investigating ARIDIA mutations and protein expression in endometriosis.

\begin{tabular}{|c|c|c|c|c|}
\hline $\begin{array}{c}\text { Authors, year of } \\
\text { publication } \\
\end{array}$ & Endometriosis samples & Loss of ARID1A protein expression & $\begin{array}{c}A R I D 1 A \text { mutations by } \\
\text { sequencing }\end{array}$ & Ref. \\
\hline $\begin{array}{l}\text { Wiegand et al., } \\
\qquad 2010\end{array}$ & $\begin{array}{l}\text { Two cases with atypical endometriosis } \\
\text { adjacent to } A R I D 1 A \text {-deficient OCCC } \\
\text { (adjacent and distant endometriosis was } \\
\text { investigated from both cases) }\end{array}$ & $\begin{array}{l}\text { In two patients, loss of ARID1A expression } \\
\text { were evident in the tumor and contiguous } \\
\text { atypical endometriosis, but not in distant } \\
\text { endometriotic lesions }\end{array}$ & $\begin{array}{l}\text { ARIDIA mutations in the } \\
\text { tumor and contiguous } \\
\text { atypical endometriosis, but } \\
\text { not in distant endometriosis }\end{array}$ & [1] \\
\hline $\begin{array}{l}\text { Wiegand et al., } \\
2011\end{array}$ & 10 cases of atypical endometriosis & $\begin{array}{l}\text { Loss of ARID1A expression in } 1 \text { of } 10 \text { samples } \\
\text { in the atypical areas, with retention in } \\
\text { non-atypical endometriosis }\end{array}$ & - & {$[87]$} \\
\hline $\begin{array}{l}\text { Yamamoto et al., } \\
2012\end{array}$ & $\begin{array}{l}59 \text { endometriotic lesions present in } 90 \\
\text { cases of OCCC ( } 28 \text { cases adjacent to } \\
\text { tumor samples) }\end{array}$ & $\begin{array}{l}\text { Complete loss of ARID1A expression in } \\
28 \text { endometriotic samples, of those, } \\
17 \text { adjacent to tumor tissue }\end{array}$ & - & {$[102]$} \\
\hline $\begin{array}{l}\text { Yamamoto et al., } \\
2012\end{array}$ & $\begin{array}{l}22 \text { solitary benign endometriosis samples } \\
\text { and } 28 \text { endometriosis samples ( } 14 \\
\text { non-atypical and } 14 \text { atypical) issuing } \\
\text { from } 17 \text { patients with ARIDIA-deficient } \\
\text { endometriosis-associated } \\
\text { ovarian carcinomas }\end{array}$ & $\begin{array}{l}\text { All the } 22 \text { non-tumor associated endometriosis } \\
\text { samples were ARID1A positive; } 12(86 \%) \text { of } \\
\text { the } 14 \text { tumor associated non-atypical } \\
\text { endometrioses were ARID1A-deficient, } \\
\text { and all of the } 14 \text { atypical endometrioses were } \\
\text { ARID1A-deficient }\end{array}$ & - & {$[101]$} \\
\hline $\begin{array}{l}\text { Samartzis et al., } \\
2012\end{array}$ & $\begin{array}{l}74 \text { samples of non-atypical } \\
\text { endometriosis: ovarian }(n=27) \text {, } \\
\text { peritoneal }(n=19) \text {; deep-infiltrating } \\
(n=28) ; 30 \text { samples of normal } \\
\text { endometrium as control }\end{array}$ & $\begin{array}{l}\text { Complete lack of ARID1A expression was } \\
\text { observed in three endometriomas }(n=3 / 20 \text {, } \\
15 \%) \text { and one deep-infiltrating endometriosis } \\
\text { sample }(n=1 / 22,5 \%) \text {; in addition, clonal } \\
\text { expression loss was observable in cases of } \\
\text { partially negative ARID1A expression }\end{array}$ & - & {$[104]$} \\
\hline $\begin{array}{l}\text { Ayhan et al., } \\
\qquad 2012\end{array}$ & $\begin{array}{l}15 \text { discrete endometriotic foci remote } \\
\text { from endometriotic cyst and } \\
\text { ovarian carcinoma; } \\
4 \text { ovarian endometriomas without } \\
\text { carcinoma and } 6 \text { cases of peritoneal } \\
\text { endometriosis as controls }\end{array}$ & All cases retained ARID1A expression & - & [105] \\
\hline Xiao et al., 2012 & $\begin{array}{l}36 \text { cases of solitary ovarian endometriosis; } \\
\text { normal eutopic endometrium as control }\end{array}$ & $\begin{array}{l}\text { Loss of ARID1A expression in } 20 \% \text { of benign } \\
\text { endometriomas; normal endometrium retained } \\
\text { ARID1A expression }\end{array}$ & - & {$[106]$} \\
\hline
\end{tabular}

This observation sustains the theory of $A R I D 1 A$ being a tumor suppressor in which loss of expression occurs in cell clones that are undergoing a process of precancerous alteration. However, it remains controversial at which stage of pathogenesis ARID1A mutations occur in endometriosis, i.e., if 
they are limited to atypical endometriosis or if they already occur in a low-frequent manner in non-atypical endometriosis or at the early transition stage from non-atypical to atypical endometriosis.

To date, $A R I D 1 A$ sequencing studies are lacking in non-carcinoma-related endometriosis, probably due to the fact that the occurrence of $A R I D I A$ mutations is expected to be low in endometriosis (considering that the relative risk to developing ovarian cancer during a lifetime is approximately $1.5 \%$ ) and that $A R I D 1 A$ sequencing studies are technically challenging, due to the large size of the gene and the random distribution of the mutations along the gene. Nevertheless, immunohistochemical data from different studies indicated that loss of ARID1A expression is also observable in rare cases of non-atypical endometriosis, especially in endometriotic cysts of the ovary, also referred to as endometriomas $[101,104,106]$. An overview of the studies that investigated ARID1A expression in endometriosis with or without relation to ovarian carcinomas is given in Table 2.

Despite the good correlation between the immunohistochemical negative ARID1A expression and its mutations ( $c f$. Section 2.4.), it is not definitely clarified if these observations are the result of ARIDIA mutations or epigenetic regulation. Sequencing analyses and further functional studies are warranted to elucidate the exact time point of the occurrence of ARIDIA mutations and their role in (atypical) endometriosis.

\subsection{Correlation between ARID1A Mutations and Loss of ARIDIA Expression in Immunohistochemistry}

In addition to Wiegand et al. [1], other groups found a strong correlation between ARIDIA mutations and loss of ARID1A protein expression in different tumor types. Guan et al. [88], in addition to a large IHC analysis of 995 tumor samples of various localizations, sequenced ARIDIA in a total of 93 tumor samples and found $10(40 \%)$ of 25 uterine endometrioid carcinomas mutated (all of them insertion/deletion or nonsense mutations), whereas none $(0 \%)$ of 12 uterine serous carcinomas and none $(0 \%)$ of 56 ovarian serous and mucinous carcinomas revealed somatic mutations in ARIDIA. They correlated the ARID1A status and IHC in the 25 uterine endometrioid carcinomas and in 51 ovarian serous carcinomas and found a significant correlation of ARID1A expression with its mutational status $(p=0.0014)$. Interestingly, they found an immunohistochemical pattern of clonal loss in ARIDIA mutated carcinomas, which was not found in ARIDIA wild-type carcinomas. This clonal loss of ARID1A protein expression was observed in four cases, which were classified as immunohistochemically positive, but genetically harbored ARIDIA mutations. When combining these cases with completely negative ones, they found an even stronger correlation of mutational status and IHC $(p<0.0001)$ [88]. In a smaller study performed in OCCC, there was a concordance of ARID1A immunohistochemistry in $91 \%$ of 12 OCCC cases with known ARIDIA mutational status with a sensitivity of $100 \%$ and a specificity of $66 \%$ [99]. In gastric adenocarcinomas, Zang et al. found a reduced or absent ARID1A protein expression in 75\% (6/8) of ARID1A mutated samples and a strong positivity for ARID1A protein expression in $100 \%$ (11/11) of the samples with wild-type ARIDIA sequence [92]. Wang et al. sequenced $A R I D 1 A$ in a total of 109 gastric cancers. They found 32 samples with $A R I D 1 A$ mutations, which, as discovered in OCCC and EnOC, were truncating in the majority of cases (85\%). Seventy-five percent (24/32) of gastric cancers with ARIDIA mutations immunohistochemically exhibited a loss or substantially lower ARID1A protein expression compared 
to cancers with the wild-type gene $(p<0.001)$ [91]. Taken together, these results suggest that an immunohistochemical loss of ARID1A expression correlates well, although not perfectly, with truncating ARIDIA mutations, which justifies its use as a surrogate marker for the underlying gene mutations $[87,101,104,107-109]$.

\section{PI3K/AKT-Pathway Alterations}

\subsection{Introduction}

Activation of the phosphatidylinositol 3-kinase (PI3K)/AKT pathway supports multiple mechanisms responsible for cancer progression, including proliferation, inhibition of apoptosis, cell adhesion and transformation. PI3K activation, e.g., by activating mutations of PIK3CA encoding the catalytic subunit, p110alpha, leads to an activation of AKT, a serine-threonine kinase, which is present in three different isoforms (AKT1-3) in human cancer and leads to increased cellular growth and survival of cancer cells [110]. The mammalian target of rapamycin complex 1 (mTORC1) is one of the major effectors downstream of AKT and is central in controlling cell growth and proliferation. mTORC1 was discovered through its inhibition by the drug, rapamycin [111,112]. Activation of the $\mathrm{PI} 3 \mathrm{~K} / \mathrm{AKT}$ pathway is mainly effected by the activation of receptor tyrosine kinases and by somatic mutations in specific components of the signaling pathway. These mainly include loss of the tumor suppressor, PTEN, activating mutations of p110alpha (PIK3CA) and, less frequently, of the three isoforms of $A K T 1$-3. In addition, amplifications of $A K T 1$ and $A K T 2$, as well as of PIK3CA have been described in some cancers, but seem to play a subordinate role compared to the other described mechanisms [110].

\subsection{PI3K/AKT Pathway Activation in Endometriosis}

Several studies have reported PI3K/AKT pathway activation in endometriosis [113-120]. It has been shown that the PI3K/AKT pathway regulates FOXO1 protein levels, a member of the forkhead-box $\mathrm{O}$ family and the decidua-specific gene IGF binding protein-1 (IGFBP-1), which are both involved in the decidualization of endometrial cells. Levels of phospho-AKT (Ser473) were consistently higher in endometriotic stromal cells, and overactivation of PI3K/AKT led to reduced decidualization in primary endometriotic stromal cells issuing from endometriomas [113]. Reduced decidualization and IGFBP-1 secretion have also been observed in primary endometriotic cells from other localizations [121] and in eutopic endometrial stromal cells from women with endometriosis [122,123]. Decidualization of the endometrium is a remodeling event that is physiologically occurring in response to progesterone in the secretory phase of the menstrual cycle in order to prepare the endometrium for the implantation of the embryo [124]. It is known that progestins and cAMP decrease phosphorylated AKT levels and increase nuclear FOXO1 levels in eutopic endometrial stromal cells [125,126]. The response to decidual stimuli by medroxyprogesterone acetate and dibutyryl cAMP was dramatically lower in ectopic endometriotic stromal cells. Interestingly, both inhibition of PI3K and AKT led to increasing nuclear FOXO1 and IGFBP1 levels in response to treatment with medroxyprogesterone acetate and dibutyryl cAMP, supporting evidence that the increased PI3K/AKT pathway is involved in the reduced decidual response in endometriosis [113]. This observation is further interesting, since it 
may indicate that the PI3K/AKT pathway is involved in processes supporting the effects of progesterone resistance, a well-described characteristic of endometriosis [127]. Therefore, small molecule inhibitors may be preclinically investigated as a therapeutic option, especially in overcoming progesterone resistance in endometriosis [113].

\subsection{PI3K/AKT Pathway Alterations in OCCC and EnOC}

In contrast to high-grade serous ovarian carcinomas, where activation of the PI3K/AKT pathway through mutation of PIK3CA, AKT or inactivating mutations of $P T E N$ is rather rare $(<5 \%)$, it is a clearly more frequent event in OCCC and EnOC [128]. Activating mutations in PIK3CA encoding p110 $\alpha$, the catalytic subunit of PI3K, have been described to occur in $33 \%-40 \%$ of OCCC $[2,129]$. Activation of the PI3K/AKT pathway by loss of PTEN expression has been found in $40 \%$ of OCCC [130]. Finally, AKT2 amplification was observed in 14\% of OCCC [131]. It is still unclear if aberrations in the PI3K/AKT pathway are critical drivers of cancer growth and, therefore, a possible therapeutic target in ovarian cancers [128]. Nevertheless, preclinical and clinical phase-I studies have suggested that inhibition of this pathway may help to overcome resistance to chemotherapy in ovarian cancer [132], which is a common problem in OCCC and, therefore, would be of specially great interest in this tumor type [52].

\subsection{PIK3CA Mutations in Endometriosis-Associated Ovarian Cancer and Endometriosis}

PIK3CA mutations, as a common mechanism of PI3K/AKT pathway activation in OCCC [133], will be discussed here in detail, since they are frequently associated with $A R I D 1 A$ mutations ( $c f$. Section 4.2.).

Activating mutations in the PIK3CA gene, encoding the p1 $10 \alpha$ subunit of PI3K, have been observed at a frequency of $33 \%-40 \%$ in OCCC [2,129]. Kuo et al. [129] first reported the high frequency of activating PIK3CA mutations in a large cohort of 97 OCCC, including 18 affinity-purified tumor cells from fresh specimen, 69 samples of microdissected paraffin-embedded tumors and 10 OCCC cell lines. They described an overall frequency of 33\% PIK3CA mutations and of $46 \%$ in the 28 affinity-purified OCCCs and OCCC cell lines. The majority of the PIK3CA mutations were confined to exons 9 and 20, leading to an activation of p110 $\alpha$ kinase. This was confirmed by immunohistochemistry, demonstrating an intense diffuse phosphorylated AKT immunoreactivity in all of the 18 specimens with PIK3CA mutations. This was also observed in PIK3CA wild-type tumors in $34(85 \%)$ of 40 cases, indicating that other mechanisms are contributing to AKT phosphorylation in a large proportion of OCCCs with wild-type PIK3CA [129].

Yamamoto et al. [134] sequenced exon 9 and 20 of PIK3CA in 23 OCCC samples and found 10 tumors (43\%) with activating mutations (H1047R in all cases). Interestingly, they observed the same mutations not only in nine adjacent atypical endometrioses of the 10 cases (90\%), but they found non-atypical endometriotic tissue in six of the 10 samples $(60 \%)$ with the same H1047R mutation, suggesting that these mutations occur very early in the tumorigenesis of OCCC [134].

An overview of studies that investigated PIK3CA mutations in OCCC and EnOC, as well as in endometriosis, is given in Tables 3 and 4, respectively. 
Table 3. PIK3CA mutations in OCCC and EnOC.

\begin{tabular}{|c|c|c|c|}
\hline $\begin{array}{c}\text { Authors, year of } \\
\text { publication }\end{array}$ & Samples & PIK3CA mutations & Ref. \\
\hline $\begin{array}{l}\text { Campbell et al., } \\
\quad 2004\end{array}$ & $\begin{array}{l}167 \text { primary epithelial ovarian carcinomas, of which, } \\
40 \text { were samples of EnOC and OCCC and } 88 \text { were } \\
\text { samples of serous ovarian carcinomas (all coding } \\
\text { exons of PIK3CA analyzed) }\end{array}$ & $\begin{array}{l}\text { PIK3CA mutations in } 8(20 \%) \text { of } 40 \text { EnOC and OCCC } \\
\text { compared to only } 2(2.3 \%) \text { of } 88 \text { in serous ovarian carcinomas } \\
(p=0.001) \text {; mutation or gene amplification of PIK3CA was } \\
\text { found in a total of } 45 \% \text { of OCCC and EnOC }\end{array}$ & [135] \\
\hline Wang et al., 2005 & $\begin{array}{l}109 \text { advanced ovarian carcinomas, including inter alia } \\
2 \text { OCCC and } 5 \text { EnOC, as well as } 90 \text { serous and } 4 \\
\text { mucinous ovarian carcinomas (PIK3CA exon } 9 \text { and } \\
20 \text { analyzed) }\end{array}$ & $\begin{array}{l}\text { A total of } 4 \text { activating missense PIK } 3 C A \text { mutations in } 109 \\
\text { tumors were found (in } 1 \text { of } 2 \text { OCCC, } 1 \text { mucinous and } 2 \text { serous } \\
\text { ovarian carcinomas) }\end{array}$ & [136] \\
\hline $\begin{array}{l}\text { Levine et al., } \\
\qquad 2005\end{array}$ & $\begin{array}{l}198 \text { unselected invasive epithelial ovarian carcinomas } \\
\text { (exon } 9 \text { and } 20 \text { analyzed) }\end{array}$ & $\begin{array}{l}\text { PIK3CA mutations in } 24 \text { of } 198 \text { (12\%) ovarian carcinomas } \\
\text { (not significantly different between different } \\
\text { histological subtypes) }\end{array}$ & [137] \\
\hline $\begin{array}{l}\text { Willner et al., } \\
\qquad 2007\end{array}$ & $\begin{array}{l}12 \mathrm{OCCC}, 26 \mathrm{EnOC} \text { and } 51 \text { serous } \\
\text { ovarian carcinomas }\end{array}$ & $\begin{array}{l}\text { Mutations in } 3 \text { of } 12(25 \%) \text { OCCC, in } 3 \text { of } 26(12 \%) \text { EnOC, but } \\
\text { in none of } 51 \text { serous ovarian carcinomas } \\
\text { PIK3CA gene amplification found in } 0 / 22 \text { EnOC and OCCC } \\
\text { compared to } 19 / 94(20 \%) \text { in SC }\end{array}$ & [138] \\
\hline Kuo et al., 2009 & $\begin{array}{l}97 \text { OCCC (18 OCCC with affinity-purified tumor cells } \\
\text { from fresh specimen, } 69 \text { microdissected tumors from } \\
\text { paraffin tissues, } 10 \text { tumor cell lines) }\end{array}$ & $\begin{array}{l}\text { PIK3CA mutations in } 33 \% \text { of the } 97 \text { OCCC ( } 46 \% \text { of the } 28 \\
\text { affinity-purified OCCC and OCCC cell lines) }\end{array}$ & [129] \\
\hline Jones et al., 2010 & $\begin{array}{l}\text { Whole exome sequencing in } 8 \text { OCCC samples and } \\
\text { validation in } 42 \text { OCCC (including the } 8 \text { tumor samples of } \\
\text { the discovery cohort) by Sanger sequencing of all exon }\end{array}$ & $\begin{array}{l}\text { Mutations of PIK3CA in } 40 \% \text { of the } 42 \text { tumors (a total of } 17 \\
\text { mutations), the majority at codons } 542,545,546 \text { or } 1,047\end{array}$ & [2] \\
\hline $\begin{array}{l}\text { Yamamoto et al., } \\
2011\end{array}$ & 23 OCCC (sequencing of PIK3CA exons 9 and 20) & $\begin{array}{l}\text { PIK3CA mutations in } 10(43 \%) \text { of } 23 \text { OCCC }(\mathrm{H} 1047 \mathrm{R} \\
\text { mutations in the kinase domain in all cases })\end{array}$ & [134] \\
\hline $\begin{array}{l}\text { Yamamoto et al., } \\
\qquad 2012\end{array}$ & $\begin{array}{l}42 \text { OCCC ( } 28 \text { endometriosis-associated cases and } 14 \\
\text { clear-cell adenofibroma-associated carcinoma cases } \\
\text { (sequencing of exons } 9 \text { and } 20 \text { ) }\end{array}$ & $\begin{array}{l}17(40 \%) \text { of the } 42 \text { OCCC harboring PIK3CA mutations } \\
\text { (majority of them ARID1A-deficient carcinomas }(71 \%) \text {, } \\
\text { suggesting frequent co-occurrence of mutations in these two genes }\end{array}$ & [101] \\
\hline $\begin{array}{l}\text { Yamamoto et al., } \\
2012\end{array}$ & $\begin{array}{l}90 \text { cases of OCCC (including } 42 \text { cases previously examined } \\
\text { in [101]; sequencing of PIK3CA exons } 9 \text { and 20) }\end{array}$ & $\begin{array}{l}\text { PIK3CA mutations found in } 34(39 \%) \text { of } 88 \text { informative } \\
\text { OCCC cases }\end{array}$ & [102] \\
\hline $\begin{array}{l}\text { Rahman et al., } \\
\qquad 2012\end{array}$ & $\begin{array}{l}\text { Mutational analysis of PIK3CA (exons } 1,9,20 \text { ) and } \\
\text { immunohistochemistry for phospho-AKT and -mTOR } \\
\text { in } 56 \text { OCCC samples } \\
13 \text { ovarian carcinoma cell lines ( } 4 \text { serous, } 9 \text { clear cell) } \\
\text { for in vitro inhibitor studies }\end{array}$ & $\begin{array}{l}\text { Missense mutations in } 16(28.6 \%) \text { of } 56 \text { OCCC tumor samples } \\
\text { No correlation of PIK3CA mutations with the } \\
\text { immunohistochemical pattern of phosphorylated AKT or mTOR } \\
\text { No correlation of PIK3CA mutations with sensitivity to } \\
\text { PI3K/AKT/mTOR inhibitors in OCCC cell lines }\end{array}$ & [139] \\
\hline $\begin{array}{l}\text { McConechy et al., } \\
2013\end{array}$ & $\begin{array}{l}\text { Select exon capture sequencing in } 33 \text { EnOC samples in } \\
\text { addition to } 307 \text { endometrial } \\
\text { endometrioid carcinomas }\end{array}$ & $\begin{array}{l}12(40 \%) \text { of } 30 \text { EnOC mutated in PIK } 3 C A .107(39 \%) \text { of } \\
307 \text { low-grade endometrial endometrioid carcinomas } \\
\text { mutated in PIK3CA }\end{array}$ & [140] \\
\hline
\end{tabular}


Table 4. PIK3CA mutations in endometriosis.

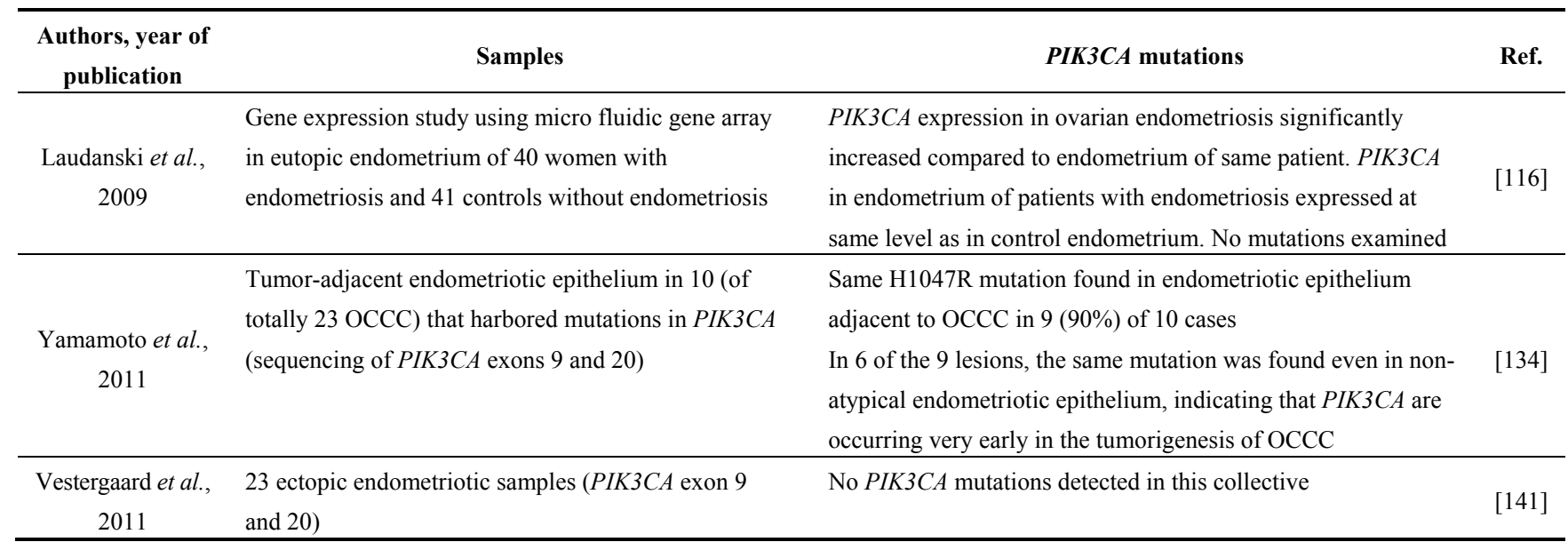

\subsection{Targeting the PI3K/AKT-Pathway in OCCC and EnOC}

$\mathrm{PI} 3 \mathrm{~K} / \mathrm{AKT} / \mathrm{mTOR}$ signaling is frequently altered in EnOC and OCCC, but it is unclear whether these genetic changes are critical drivers for these carcinomas. It is therefore questionable whether these molecules are susceptible to targeted inhibition and suitable for response prediction. Several $\mathrm{PI} 3 \mathrm{~K} / \mathrm{AKT} / \mathrm{mTOR}$ inhibitors were explored as single agents or in combination in clinical trials of different tumor types. In ovarian and endometrial cancers, significant single-agent activity with $\mathrm{PI} 3 \mathrm{~K} / \mathrm{AKT}$ inhibitors is rarely observed [142,143]. However, it is known that PI3K/AKT activation contributes to a reduced response to chemotherapy in ovarian cancer [144] and that modulation of the $\mathrm{PI} 3 \mathrm{~K} / \mathrm{AKT} / \mathrm{mTOR}$ pathway is suitable for overcoming resistance to chemotherapy [132]. Thus, Mabuchi et al. demonstrated increased sensitivity of cisplatin-resistant OCCC cell lines to the mTOR inhibitor everolimus, compared to the cisplatin-sensitive parental OCCC cell lines [145].

To date, reliable biomarkers for the prediction of response to therapy in ovarian cancer are not in clinical use [146]. In the past, several studies have explored the effects of PI3K/AKT/mTOR inhibitors on human cancer cells. In a study of several OCCC cells, PIK3CA mutations did not predict the sensitivity to PI3K/AKT/mTOR inhibitors [139]. In contrast, activated AKT was a predictive marker of drug sensitivity in ovarian cancer cells, which were treated with RAD001 (everolimus) to inhibit the mTOR pathway [147].

In a recent study, seven patients with advanced ovarian carcinomas harboring a PI3KCA mutation were enrolled onto clinical trials that included a PI3K/AKT/mTOR inhibitor. Prior to that, all patients had experienced treatment failure with standard therapies. Two patients $(2 / 7,29 \%)$ responded to this targeted therapy, which was combined with a cytotoxic drug. Other gynecologic and breast carcinomas in this study cohort also demonstrated a higher response rate than patients without PIK3CA mutations. Despite the small sample size, the authors conclude that $P I K 3 C A$ mutation screening is helpful in the use of PI3K/AKT/mTOR pathway inhibition. However, single-agent use seems to not be sufficient to induce a response, because PIK3CA mutations often coexist with other concurrent molecular aberrations. Interestingly, both responders of the ovarian cancer subset had a simultaneous MAPK pathway mutation (one each in $K R A S$ and $B R A F$ ) [142].

It is known that PI3K/AKT/mTOR signaling is a complex process, which interacts with the RAS/RAF/MEK/ERK pathway. In this context, it was observed that PIK3CA mutations may predict 
the response to $\mathrm{PI} 3 \mathrm{~K} / \mathrm{AKT} / \mathrm{mTOR}$ inhibitors, whereas concomitant mutations in the MAPK pathway (KRAS, NRAS, BRAF) may mediate resistance [148,149]. Therefore, clinical trials investigate several strategies, like dual targeting of PI3K/AKT/mTOR and RAF/MEK/ERK pathways, as well as the combination of multi-drugs instead of single-agents $[128,150]$.

\section{Further Implications}

\subsection{Functional Studies about the Loss of ARID1A Expression In Vitro and In Vivo}

Cancer genome sequencing studies have created a new perspective about disordered chromatin organization as a feature of cancer, showing that mutations of epigenetic regulators are occurring frequently in a wide variety of different human cancers. Although the subject of intensive study, the exact function and role of $A R I D I A$ as a tumor suppressor remains far from being elucidated. In vitro studies have suggested different roles for $A R I D I A$ to exert its tumor suppressive action, which are mainly through proliferation, differentiation and apoptosis [77]. Knockdown of ARIDIA led to increased proliferation of normal ovarian surface epithelial cells [84] and disrupted differentiation of certain cell types (e.g., osteoblasts) [151]. In Jurkat leukemia cells, Fas-mediated cell death was inhibited after ARIDIA knockdown [152]. ARIDIA, in contrast to the mutually exclusive ARIDIB subunit of the SWI/SNF complex, inhibited cell cycle arrest in murine preosteoblasts $[153,154]$. Although these findings all constitute promising new perspectives in understanding the function of $A R I D 1 A$ as a tumor suppressor, the functional consequences of ARIDIA mutations are probably more vast, since ARID1A regulates hundreds of different genes through the SWI/SNF chromatin remodeling complex [80]. Furthermore, it is likely that ARIDIA mutations have divergent effects, depending on different cell and tumor types in which they are present, probably also depending on the mutational landscape in different cancer types. As a result, functional studies of ARIDIA present a substantial scientific challenge [77].

\subsection{Evidence for Cooperative Mechanisms between ARIDIA and the PI3K/AKT Pathway}

Various studies are suggesting cooperating mechanisms in relation to ARIDIA mutations. Yamamoto et al. described a frequent co-occurrence between activating PIK3CA mutations and loss of ARID1A expression in OCCC, demonstrating that $46 \%$ of ARID1A deficient tumors were harboring PIK3CA mutations versus $17 \%$ of the ARID1A expressing tumors [102]. In endometrioid endometrial cancer, a higher frequency of PI3K/AKT-pathway alterations (PTEN loss or PIK3CA activating mutations) was found in tumors with a loss of ARID1A expression, and the number of tumors that showed no alteration in the PI3K/AKT-pathway was 4.6-fold higher in tumors with preserved ARID1A expression ( $p=0.042$ ) [107]. An association between PIK3CA and ARIDIA mutations has also been reported in gastric cancer [92].

It has been suggested in many studies that loss of ARID1A is usually associated with TP53 wild-type tumors [84,91,92,155], and one study showed evidence for a direct protein-protein interaction between ARID1A and p53 [84].

A very interesting study conducted by Liang et al. [156] not only identified ARIDIA as a potential driver gene in endometrial cancer, but also demonstrated that ARIDIA mutations frequently co-occur 
with mutations, leading to activation in the PI3K/AKT pathway. An important observation was that siRNA knockdown of ARIDIA in endometrial cancer cell lines per se led to an increased phosphorylation of AKT, indicating a regulation of the PI3K/AKT pathway activity by ARID1A [156].

A recent study in $S M A R C B 1$, a potent tumor suppressor with loss of expression, especially in certain rhabdoid tumor types and which is a core subunit of the SWI/SNF complex, showed persistent activation of AKT in SMARCB1-deficient tumor cells, contributing to survival and proliferation. Inhibition of AKT was sufficient to inhibit development of SMARCB1-deficient xenograft-tumors and to inhibit proliferation of SMARCB1-deficient cells in vitro [157].

Remarkable results have been presented at the 104th Annual Meeting of the American Association for Cancer Research by Guan et al. [158]: The authors tested the possibility of molecular dependency of ARIDIA and the PI3K/PTEN pathway in an ARIDIA knockout mice and ARIDIA/PTEN double knockout mice model. After conditional depletion of either $A R I D I A(n=10)$ or simultaneously ARIDIA and PTEN $(n=12)$, the mice with knock-out of only ARIDIA did not develop histological alterations, whereas $40 \%$ of the mice with double knock-out of ARIDIA and PTEN developed poorly differentiated ovarian tumors disseminating in the peritoneal cavity and ascites. In the other $60 \%$, the authors found hyperplasia of the ovarian surface epithelium. This shows that ARID1A inactivation in itself is not sufficient to initiate tumor development and requires a second hit, possibly consistent with an alteration in the PI3K/PTEN/AKT pathway to lead to carcinogenic transformation [158].

These observations are exciting for at least two important reasons. Firstly, it may explain the observation of ARID1A expression in non-atypical endometriosis made by several groups $[101,104,106]$; loss of ARID1A expression may be an early molecular event in these cases that might increase the overall risk of developing endometriosis-associated cancer, but in itself is not sufficient to initiate cancerogenesis. Secondly, it confirms that there is a close cooperative mechanism between ARIDIA mutations and PI3K/AKT pathway alterations that might be of importance for early tumor detection, as well as in a therapeutic context. Interdependency on PI3K/AKT activation of ARIDIA mutated tumor clones might be a process that is targetable by small-molecule inhibitors of the $\mathrm{PI} 3 \mathrm{~K} / \mathrm{AKT} / \mathrm{mTOR}$ pathway.

\subsection{Possible Clinical Implications of ARID1A Mutations}

The question of clinical implication of $A R I D I A$ mutations is not yet thoroughly answered. Whilst there is fast growing knowledge about the distribution of mutations of ARIDIA and other members of the SWI/SNF complex in various cancers, functional and clinic-pathological data remain quite sparse.

Many studies have investigated ARIDIA mutations as prognostic markers in a multitude of different cancers, such as OCCC, as well as breast, gastric and bladder cancer [91,93,97,100,102,155,159-161], but to date, none have demonstrated a consistent prognostic significance of ARIDIA mutational or expressional status. This may be partially due to the lack of larger prospective studies [77]. On the other hand, it has also to be answered if an early loss of ARID1A expression and/or PIK3CA mutation represents an increased probability for developing OCCC or EnOC in endometriosis $[3,101,104,106]$. Last, but not least, it will be of major interest to determine whether ARIDIA inactivation may be therapeutically exploited by targeting downstream and potentially reversible epigenetic gene 
expression targets altered by remodeler mutations, such as, e.g., oncogenic proteins cyclin D1 and MYC or alterations in the Hedgehog pathway signaling [77,133,162].

An interesting synthetic-lethality therapy principle involving the SWI/SNF catalytic subunit, $B R G 1 / S M A R C A 4$, frequently deficient in non-small-cell lung carcinomas by BRM-ATPase inhibitors targeting another SWI/SNF subunit, has been proposed in a recent study [163]. This demonstrates that although the effects of SWI/SNF subunit mutations are very complex and still poorly understood, their respective downstream effectors are potentially targetable by compounds, opening a wide horizon of mechanisms that may be influenced for therapeutic purposes.

\section{Conclusions}

Although still at the beginning, the current genomic characterizations of ARIDIA mutations and functional investigations of the loss of ARID1A expression in vitro and in animal studies, combined with analyses of presumed cooperating pathways as, e.g., the PI3K/AKT/mTOR pathway through direct activation and mutations of PTEN or PIK3CA, opens new perspectives for potential therapeutic approaches. This is of great interest in OCCC, since this frequently endometriosis-associated ovarian carcinoma subtype is characterized by resistance to conventional chemotherapy regimens and, therefore, has a poor prognosis in advanced stages. Mutations and consecutive loss of ARID1A expression, as well as activating mutations in the PI3K/AKT pathway (through loss of PTEN expression or PIK3CA activation) are highly frequent in OCCC and have to be further assessed in potential therapeutic strategies. The current intensified research activity in this field promises improved understanding and relevant progress in clinically significant aspects in the near future.

\section{Acknowledgments}

This work was supported by a grant from the Center for Clinical Research, University and University Hospital Zurich, as well as by a grant from Hartmann-Muller Stiftung. The authors wish to express their sincere thanks to Victor Moll, for reviewing language style and grammar in the manuscript.

\section{Conflicts of Interest}

The authors declare no conflict of interest.

\section{References}

1. Cornen, S.; Adelaide, J.; Bertucci, F.; Finetti, P.; Guille, A.; Birnbaum, D.J.; Birnbaum, D.; Chaffanet, M. Mutations and deletions of aridla in breast tumors. Oncogene 2012, 31, 4255-4256.

2. Popovic, R.; Licht, J.D. Emerging epigenetic targets and therapies in cancer medicine. Cancer Discov. 2012, 2, 405-413.

3. Oike, T.; Ogiwara, H.; Tominaga, Y.; Ito, K.; Ando, O.; Tsuta, K.; Mizukami, T.; Shimada, Y.; Isomura, H.; Komachi, M.; et al. A synthetic lethality-based strategy to treat cancers harboring a genetic deficiency in the chromatin remodeling factor brg1. Cancer Res. 2013, doi:10.1158/0008-5472.CAN-12-4593. 
4. Wiegand, K.C.; Shah, S.P.; Al-Agha, O.M.; Zhao, Y.; Tse, K.; Zeng, T.; Senz, J.; McConechy, M.K.; Anglesio, M.S.; Kalloger, S.E.; et al. Aridla mutations in endometriosis-associated ovarian carcinomas. N. Engl. J. Med. 2010, 363, 1532-1543.

5. Jones, S.; Wang, T.L.; Shih, I.M.; Mao, T.L.; Nakayama, K.; Roden, R.; Glas, R.; Slamon, D.; Diaz, L.A.; Vogelstein, B.; et al. Frequent mutations of chromatin remodeling gene aridla in ovarian clear cell carcinoma. Science 2010, 330, 228-231.

6. Birrer, M.J. The origin of ovarian cancer-Is it getting clearer? N. Engl. J. Med. 2010, 363, 1574-1575.

7. Nissenblatt, M. Endometriosis-associated ovarian carcinomas. N. Engl. J. Med. 2011, 364, 482-483.

8. Bulun, S.E. Endometriosis. N. Engl. J. Med. 2009, 360, 268-279.

9. Buck Louis, G.M.; Hediger, M.L.; Peterson, C.M.; Croughan, M.; Sundaram, R.; Stanford, J.; Chen, Z.; Fujimoto, V.Y.; Varner, M.W.; Trumble, A.; et al. Incidence of endometriosis by study population and diagnostic method: The endo study. Fertil. Steril. 2011, 96, 360-365.

10. Giudice, L.C.; Kao, L.C. Endometriosis. Lancet 2004, 364, 1789-1799.

11. Giudice, L.C. Clinical practice. Endometriosis. N. Engl. J. Med. 2010, 362, 2389-2398.

12. Somigliana, E.; Vigano', P.; Parazzini, F.; Stoppelli, S.; Giambattista, E.; Vercellini, P. Association between endometriosis and cancer: A comprehensive review and a critical analysis of clinical and epidemiological evidence. Gynecol. Oncol. 2006, 101, 331-341.

13. Sampson, J.A. Endometrial carcinoma of the ovary, arising in endometrial tissue in that organ. Arch. Surg. 1925, 10, 1-72.

14. Ness, R.B. Endometriosis and ovarian cancer: Thoughts on shared pathophysiology. Am. J. Obstet. Gynecol. 2003, 189, 280-294.

15. Brinton, L.A.; Gridley, G.; Persson, I.; Baron, J.; Bergqvist, A. Cancer risk after a hospital discharge diagnosis of endometriosis. Am. J. Obstet. Gynecol. 1997, 176, 572-579.

16. Melin, A.; Sparen, P.; Persson, I.; Bergqvist, A. Endometriosis and the risk of cancer with special emphasis on ovarian cancer. Hum. Reprod. 2006, 21, 1237-1242.

17. Kobayashi, H.; Sumimoto, K.; Moniwa, N.; Imai, M.; Takakura, K.; Kuromaki, T.; Morioka, E.; Arisawa, K.; Terao, T. Risk of developing ovarian cancer among women with ovarian endometrioma: A cohort study in shizuoka, Japan. Int. J. Gynecol. Cancer 2007, 17, 37-43.

18. Rossing, M.A.; Cushing-Haugen, K.L.; Wicklund, K.G.; Doherty, J.A.; Weiss, N.S. Risk of epithelial ovarian cancer in relation to benign ovarian conditions and ovarian surgery. Cancer Causes Control 2008, 19, 1357-1364.

19. Wu, A.H.; Pearce, C.L.; Tseng, C.C.; Templeman, C.; Pike, M.C. Markers of inflammation and risk of ovarian cancer in los angeles county. Int. J. Cancer 2009, 124, 1409-1415.

20. Ness, R.B.; Cramer, D.W.; Goodman, M.T.; Kjaer, S.K.; Mallin, K.; Mosgaard, B.J.; Purdie, D.M.; Risch, H.A.; Vergona, R.; Wu, A.H. Infertility, fertility drugs, and ovarian cancer: A pooled analysis of case-control studies. Am. J. Epidemiol. 2002, 155, 217-224.

21. Merritt, M.A.; Green, A.C.; Nagle, C.M.; Webb, P.M.; Cancer, A.C.S.O.; Group, A.O.C.S. Talcum powder, chronic pelvic inflammation and nsaids in relation to risk of epithelial ovarian cancer. Int. J. Cancer 2008, 122, 170-176.

22. Venn, A.; Watson, L.; Bruinsma, F.; Giles, G.; Healy, D. Risk of cancer after use of fertility drugs with in vitro fertilisation. Lancet 1999, 354, 1586-1590. 
23. Borgfeldt, C.; Andolf, E. Cancer risk after hospital discharge diagnosis of benign ovarian cysts and endometriosis. Acta Obstet. Gynecol. Scand. 2004, 83, 395-400.

24. Brinton, L.A.; Sakoda, L.C.; Sherman, M.E.; Frederiksen, K.; Kjaer, S.K.; Graubard, B.I.; Olsen, J.H.; Mellemkjaer, L. Relationship of benign gynecologic diseases to subsequent risk of ovarian and uterine tumors. Cancer Epidemiol. Biomark. Prev. 2005, 14, 2929-2935.

25. Ness, R.B.; Grisso, J.A.; Cottreau, C.; Klapper, J.; Vergona, R.; Wheeler, J.E.; Morgan, M.; Schlesselman, J.J. Factors related to inflammation of the ovarian epithelium and risk of ovarian cancer. Epidemiology 2000, 11, 111-117.

26. Brinton, L.A.; Lamb, E.J.; Moghissi, K.S.; Scoccia, B.; Althuis, M.D.; Mabie, J.E.; Westhoff, C.L. Ovarian cancer risk associated with varying causes of infertility. Fertil. Steril. 2004, 82, 405-414.

27. Vercellini, P.; Parazzini, F.; Bolis, G.; Carinelli, S.; Dindelli, M.; Vendola, N.; Luchini, L.; Crosignani, P.G. Endometriosis and ovarian cancer. Am. J. Obstet. Gynecol. 1993, 169, 181-182.

28. Pearce, C.L.; Templeman, C.; Rossing, M.A.; Lee, A.; Near, A.M.; Webb, P.M.; Nagle, C.M.; Doherty, J.A.; Cushing-Haugen, K.L.; Wicklund, K.G.; et al. Association between endometriosis and risk of histological subtypes of ovarian cancer: A pooled analysis of case-control studies. Lancet Oncol. 2012, 13, 385-394.

29. Sieh, W.; Kobel, M.; Longacre, T.A.; Bowtell, D.D.; Defazio, A.; Goodman, M.T.; Hogdall, E.; Deen, S.; Wentzensen, N.; Moysich, K.B.; et al. Hormone-receptor expression and ovarian cancer survival: An ovarian tumor tissue analysis consortium study. Lancet Oncol. 2013, 14, 853-862.

30. Kurman, R.J.; Shih, I.M. Molecular pathogenesis and extraovarian origin of epithelial ovarian cancer-shifting the paradigm. Hum. Pathol. 2011, 42, 918-931.

31. Kurman, R.J.; Shih, I.M. Pathogenesis of ovarian cancer: Lessons from morphology and molecular biology and their clinical implications. Int. J. Gynecol. Pathol. 2008, 27, 151-160.

32. Shih, I.M.; Kurman, R.J. Ovarian tumorigenesis: A proposed model based on morphological and molecular genetic analysis. Am. J. Pathol. 2004, 164, 1511-1518.

33. Shih, I.M.; Kurman, R.J. Molecular pathogenesis of ovarian borderline tumors: New insights and old challenges. Clin. Cancer Res. 2005, 11, 7273-7279.

34. Kurman, R.J.; Visvanathan, K.; Roden, R.; Wu, T.C.; Shih, I.M. Early detection and treatment of ovarian cancer: Shifting from early stage to minimal volume of disease based on a new model of carcinogenesis. Am. J. Obstet. Gynecol. 2008, 198, 351-356.

35. Vang, R.; Shih, I.M.; Kurman, R.J. Fallopian tube precursors of ovarian low- and high-grade serous neoplasms. Histopathology 2013, 62, 44-58.

36. Dubeau, L. The cell of origin of ovarian epithelial tumours. Lancet Oncol. 2008, 9, 1191-1197.

37. Hough, C.D.; Sherman-Baust, C.A.; Pizer, E.S.; Montz, F.J.; Im, D.D.; Rosenshein, N.B.; Cho, K.R.; Riggins, G.J.; Morin, P.J. Large-scale serial analysis of gene expression reveals genes differentially expressed in ovarian cancer. Cancer Res. 2000, 60, 6281-6287.

38. Dubeau, L. The cell of origin of ovarian epithelial tumors and the ovarian surface epithelium dogma: Does the emperor have no clothes? Gynecol. Oncol. 1999, 72, 437-442.

39. Crum, C.P.; Drapkin, R.; Miron, A.; Ince, T.A.; Muto, M.; Kindelberger, D.W.; Lee, Y. The distal fallopian tube: A new model for pelvic serous carcinogenesis. Curr. Opin. Obstet. Gynecol. 2007, 19, 3-9. 
40. Roh, M.H.; Kindelberger, D.; Crum, C.P. Serous tubal intraepithelial carcinoma and the dominant ovarian mass: Clues to serous tumor origin? Am. J. Surg. Pathol. 2009, 33, 376-383.

41. Semmel, D.R.; Folkins, A.K.; Hirsch, M.S.; Nucci, M.R.; Crum, C.P. Intercepting early pelvic serous carcinoma by routine pathological examination of the fimbria. Mod. Pathol. 2009, 22, 985-988.

42. Wei, J.J.; Wu, J.; Luan, C.; Yeldandi, A.; Lee, P.; Keh, P.; Liu, J. Hmga2: A potential biomarker complement to p53 for detection of early-stage high-grade papillary serous carcinoma in fallopian tubes. Am. J. Surg. Pathol. 2010, 34, 18-26.

43. Sehdev, A.S.; Kurman, R.J.; Kuhn, E.; Shih, I.M. Serous tubal intraepithelial carcinoma upregulates markers associated with high-grade serous carcinomas including rsf-1 (hbxap), cyclin e and fatty acid synthase. Mod. Pathol. 2010, 23, 844-855.

44. Kuhn, E.; Kurman, R.J.; Vang, R.; Sehdev, A.S.; Han, G.; Soslow, R.; Wang, T.L.; Shih, I.M. Tp53 mutations in serous tubal intraepithelial carcinoma and concurrent pelvic high-grade serous carcinoma-evidence supporting the clonal relationship of the two lesions. J. Pathol. 2012, 226, 421-426.

45. Kuhn, E.; Meeker, A.; Wang, T.L.; Sehdev, A.S.; Kurman, R.J.; Shih, I.M. Shortened telomeres in serous tubal intraepithelial carcinoma: An early event in ovarian high-grade serous carcinogenesis. Am. J. Surg. Pathol. 2010, 34, 829-836.

46. Cibula, D.; Widschwendter, M.; Majek, O.; Dusek, L. Tubal ligation and the risk of ovarian cancer: Review and meta-analysis. Hum. Reprod. Update 2011, 17, 55-67.

47. Narod, S.A.; Sun, P.; Ghadirian, P.; Lynch, H.; Isaacs, C.; Garber, J.; Weber, B.; Karlan, B.; Fishman, D.; Rosen, B.; et al. Tubal ligation and risk of ovarian cancer in carriers of brca1 or brca2 mutations: A case-control study. Lancet 2001, 357, 1467-1470.

48. Miracle-McMahill, H.L.; Calle, E.E.; Kosinski, A.S.; Rodriguez, C.; Wingo, P.A.; Thun, M.J.; Heath, C.W. Tubal ligation and fatal ovarian cancer in a large prospective cohort study. Am. J. Epidemiol. 1997, 145, 349-357.

49. Hankinson, S.E.; Hunter, D.J.; Colditz, G.A.; Willett, W.C.; Stampfer, M.J.; Rosner, B.; Hennekens, C.H.; Speizer, F.E. Tubal ligation, hysterectomy, and risk of ovarian cancer. A prospective study. JAMA 1993, 270, 2813-2818.

50. Ogawa, S.; Kaku, T.; Amada, S.; Kobayashi, H.; Hirakawa, T.; Ariyoshi, K.; Kamura, T.; Nakano, H. Ovarian endometriosis associated with ovarian carcinoma: A clinicopathological and immunohistochemical study. Gynecol. Oncol. 2000, 77, 298-304.

51. Lim, M.C.; Chun, K.C.; Shin, S.J.; Lee, I.H.; Lim, K.T.; Cho, C.H.; Park, S.Y.; Nam, J.H. Clinical presentation of endometrioid epithelial ovarian cancer with concurrent endometriosis: A multicenter retrospective study. Cancer Epidemiol. Biomark. Prev. 2010, 19, 398-404.

52. Aris, A. Endometriosis-associated ovarian cancer: A ten-year cohort study of women living in the estrie region of quebec, canada. J. Ovarian Res. 2010, 3, 2.

53. Czernobilsky, B.; Morris, W.J. A histologic study of ovarian endometriosis with emphasis on hyperplastic and atypical changes. Obstet. Gynecol. 1979, 53, 318-323.

54. LaGrenade, A.; Silverberg, S.G. Ovarian tumors associated with atypical endometriosis. Hum. Pathol. 1988, 19, 1080-1084. 
55. Anglesio, M.S.; Carey, M.S.; Kobel, M.; Mackay, H.; Huntsman, D.G.; Speakers, V.O.C.C.S. Clear cell carcinoma of the ovary: A report from the first ovarian clear cell symposium, June 24th, 2010. Gynecol. Oncol. 2011, 121, 407-415.

56. Sugiyama, T.; Kamura, T.; Kigawa, J.; Terakawa, N.; Kikuchi, Y.; Kita, T.; Suzuki, M.; Sato, I.; Taguchi, K. Clinical characteristics of clear cell carcinoma of the ovary: A distinct histologic type with poor prognosis and resistance to platinum-based chemotherapy. Cancer 2000, 88, 2584-2589.

57. Itamochi, H.; Kigawa, J.; Terakawa, N. Mechanisms of chemoresistance and poor prognosis in ovarian clear cell carcinoma. Cancer Sci. 2008, 99, 653-658.

58. Mackay, H.J.; Brady, M.F.; Oza, A.M.; Reuss, A.; Pujade-Lauraine, E.; Swart, A.M.; Siddiqui, N.; Colombo, N.; Bookman, M.A.; Pfisterer, J.; et al. Prognostic relevance of uncommon ovarian histology in women with stage iii/iv epithelial ovarian cancer. Int. J. Gynecol. Cancer 2010, 20, 945-952.

59. Kobel, M.; Kalloger, S.E.; Huntsman, D.G.; Santos, J.L.; Swenerton, K.D.; Seidman, J.D.; Gilks, C.B.; Cheryl Brown Ovarian Cancer Outcomes Unit of the British Columbia Cancer Agency; Vancouver, B.C. Differences in tumor type in low-stage versus high-stage ovarian carcinomas. Int. J. Gynecol. Pathol. 2010, 29, 203-211.

60. McCluggage, W.G. My approach to and thoughts on the typing of ovarian carcinomas. J. Clin. Pathol. 2008, 61, 152-163.

61. Chan, J.K.; Teoh, D.; Hu, J.M.; Shin, J.Y.; Osann, K.; Kapp, D.S. Do clear cell ovarian carcinomas have poorer prognosis compared to other epithelial cell types? A study of 1411 clear cell ovarian cancers. Gynecol. Oncol. 2008, 109, 370-376.

62. Jacoby, V.L.; Fujimoto, V.Y.; Giudice, L.C.; Kuppermann, M.; Washington, A.E. Racial and ethnic disparities in benign gynecologic conditions and associated surgeries. Am. J. Obstet. Gynecol. 2010, 202, 514-521.

63. Takano, M.; Kikuchi, Y.; Yaegashi, N.; Kuzuya, K.; Ueki, M.; Tsuda, H.; Suzuki, M.; Kigawa, J.; Takeuchi, S.; Moriya, T.; et al. Clear cell carcinoma of the ovary: A retrospective multicentre experience of 254 patients with complete surgical staging. Br. J. Cancer 2006, 94, 1369-1374.

64. Ho, C.M.; Huang, Y.J.; Chen, T.C.; Huang, S.H.; Liu, F.S.; Chang Chien, C.C.; Yu, M.H.; Mao, T.L.; Wang, T.Y.; Hsieh, C.Y. Pure-type clear cell carcinoma of the ovary as a distinct histological type and improved survival in patients treated with paclitaxel-platinum-based chemotherapy in pure-type advanced disease. Gynecol. Oncol. 2004, 94, 197-203.

65. Pectasides, D.; Fountzilas, G.; Aravantinos, G.; Kalofonos, C.; Efstathiou, H.; Farmakis, D.; Skarlos, D.; Pavlidis, N.; Economopoulos, T.; Dimopoulos, M.A. Advanced stage clear-cell epithelial ovarian cancer: The hellenic cooperative oncology group experience. Gynecol. Oncol. 2006, 102, 285-291.

66. Utsunomiya, H.; Akahira, J.; Tanno, S.; Moriya, T.; Toyoshima, M.; Niikura, H.; Ito, K.; Morimura, Y.; Watanabe, Y.; Yaegashi, N. Paclitaxel-platinum combination chemotherapy for advanced or recurrent ovarian clear cell adenocarcinoma: A multicenter trial. Int. J. Gynecol. Cancer 2006, 16, 52-56.

67. Tan, D.S.; Kaye, S. Ovarian clear cell adenocarcinoma: A continuing enigma. J. Clin. Pathol. 2007, 60, 355-360. 
68. Duska, L.R.; Garrett, L.; Henretta, M.; Ferriss, J.S.; Lee, L.; Horowitz, N. When 'never-events' occur despite adherence to clinical guidelines: The case of venous thromboembolism in clear cell cancer of the ovary compared with other epithelial histologic subtypes. Gynecol. Oncol. 2010, 116, 374-377.

69. Collaborative Group on Epidemiological Studies of Ovarian Cancer; Beral, V.; Gaitskell, K.; Hermon, C.; Moser, K.; Reeves, G.; Peto, R. Ovarian cancer and smoking: Individual participant meta-analysis including 28,114 women with ovarian cancer from 51 epidemiological studies. Lancet Oncol. 2012, 13, 946-956.

70. Maeda, D.; Shih, I.M. Pathogenesis and the role of aridla mutation in endometriosis-related ovarian neoplasms. Adv. Anat. Pathol. 2013, 20, 45-52.

71. Eifel, P.; Hendrickson, M.; Ross, J.; Ballon, S.; Martinez, A.; Kempson, R. Simultaneous presentation of carcinoma involving the ovary and the uterine corpus. Cancer 1982, 50, 163-170.

72. Zaino, R.J.; Unger, E.R.; Whitney, C. Synchronous carcinomas of the uterine corpus and ovary. Gynecol. Oncol. 1984, 19, 329-335.

73. Ulbright, T.M.; Roth, L.M. Metastatic and independent cancers of the endometrium and ovary: A clinicopathologic study of 34 cases. Hum. Pathol. 1985, 16, 28-34.

74. Kline, R.C.; Wharton, J.T.; Atkinson, E.N.; Burke, T.W.; Gershenson, D.M.; Edwards, C.L. Endometrioid carcinoma of the ovary: Retrospective review of 145 cases. Gynecol. Oncol. 1990, 39, 337-346.

75. Falkenberry, S.S.; Steinhoff, M.M.; Gordinier, M.; Rappoport, S.; Gajewski, W.; Granai, C.O. Synchronous endometrioid tumors of the ovary and endometrium. A clinicopathologic study of 22 cases. J. Reprod. Med. 1996, 41, 713-718.

76. McMeekin, D.S.; Burger, R.A.; Manetta, A.; DiSaia, P.; Berman, M.L. Endometrioid adenocarcinoma of the ovary and its relationship to endometriosis. Gynecol. Oncol. 1995, 59, 81-86.

77. Rutgers, J.L.; Scully, R.E. Ovarian mullerian mucinous papillary cystadenomas of borderline malignancy. A clinicopathologic analysis. Cancer 1988, 61, 340-348.

78. Kim, K.R.; Choi, J.; Hwang, J.E.; Baik, Y.A.; Shim, J.Y.; Kim, Y.M.; Robboy, S.J. Endocervical-like (mullerian) mucinous borderline tumours of the ovary are frequently associated with the kras mutation. Histopathology 2010, 57, 587-596.

79. Fukunaga, M.; Ushigome, S. Epithelial metaplastic changes in ovarian endometriosis. Mod. Pathol. 1998, 11, 784-788.

80. Wu, J.N.; Roberts, C.W. Aridla mutations in cancer: Another epigenetic tumor suppressor? Cancer Discov. 2013, 3, 35-43.

81. Wilsker, D.; Probst, L.; Wain, H.M.; Maltais, L.; Tucker, P.W.; Moran, E. Nomenclature of the arid family of dna-binding proteins. Genomics 2005, 86, 242-251.

82. Wang, X.; Nagl, N.G.; Wilsker, D.; van Scoy, M.; Pacchione, S.; Yaciuk, P.; Dallas, P.B.; Moran, E. Two related arid family proteins are alternative subunits of human swi/snf complexes. Biochem. J. 2004, 383, 319-325.

83. Wilson, B.G.; Roberts, C.W. Swi/snf nucleosome remodellers and cancer. Nat. Rev. Cancer 2011, 11, 481-492. 
84. Kozmik, Z.; Machon, O.; Kralova, J.; Kreslova, J.; Paces, J.; Vlcek, C. Characterization of mammalian orthologues of the drosophila osa gene: Cdna cloning, expression, chromosomal localization, and direct physical interaction with brahma chromatin-remodeling complex. Genomics 2001, 73, 140-148.

85. Flores-Alcantar, A.; Gonzalez-Sandoval, A.; Escalante-Alcalde, D.; Lomeli, H. Dynamics of expression of aridla and arid1b subunits in mouse embryos and in cells during the cell cycle. Cell Tissue Res. 2011, 345, 137-148.

86. Beausoleil, S.A.; Jedrychowski, M.; Schwartz, D.; Elias, J.E.; Villen, J.; Li, J.; Cohn, M.A.; Cantley, L.C.; Gygi, S.P. Large-scale characterization of hela cell nuclear phosphoproteins. Proc. Natl. Acad. Sci. USA 2004, 101, 12130-12135.

87. Guan, B.; Wang, T.L.; Shih, I.M. Arid1a, a factor that promotes formation of swi/snf-mediated chromatin remodeling, is a tumor suppressor in gynecologic cancers. Cancer Res. 2011, 71, $6718-6727$.

88. Nie, Z.; Xue, Y.; Yang, D.; Zhou, S.; Deroo, B.J.; Archer, T.K.; Wang, W. A specificity and targeting subunit of a human swi/snf family-related chromatin-remodeling complex. Mol. Cell. Biol. 2000, 20, 8879-8888.

89. Shain, A.H.; Pollack, J.R. The spectrum of swi/snf mutations, ubiquitous in human cancers. PLoS One 2013, 8, e55119.

90. Wiegand, K.C.; Lee, A.F.; Al-Agha, O.M.; Chow, C.; Kalloger, S.E.; Scott, D.W.; Steidl, C.; Wiseman, S.M.; Gascoyne, R.D.; Gilks, B.; et al. Loss of baf250a (arid1a) is frequent in high-grade endometrial carcinomas. J. Pathol. 2011, 224, 328-333.

91. Guan, B.; Mao, T.L.; Panuganti, P.K.; Kuhn, E.; Kurman, R.J.; Maeda, D.; Chen, E.; Jeng, Y.M.; Wang, T.L.; Shih, I.M. Mutation and loss of expression of aridla in uterine low-grade endometrioid carcinoma. Am. J. Surg. Pathol. 2011, 35, 625-632.

92. Shain, A.H.; Giacomini, C.P.; Matsukuma, K.; Karikari, C.A.; Bashyam, M.D.; Hidalgo, M.; Maitra, A.; Pollack, J.R. Convergent structural alterations define switch/sucrose nonfermentable (swi/snf) chromatin remodeler as a central tumor suppressive complex in pancreatic cancer. Proc. Natl. Acad. Sci. USA 2012, 109, E252-E259.

93. Birnbaum, D.J.; Adelaide, J.; Mamessier, E.; Finetti, P.; Lagarde, A.; Monges, G.; Viret, F.; Goncalves, A.; Turrini, O.; Delpero, J.R.; et al. Genome profiling of pancreatic adenocarcinoma. Genes Chromosomes Cancer 2011, 50, 456-465.

94. Wang, K.; Kan, J.; Yuen, S.T.; Shi, S.T.; Chu, K.M.; Law, S.; Chan, T.L.; Kan, Z.; Chan, A.S.; Tsui, W.Y.; et al. Exome sequencing identifies frequent mutation of aridla in molecular subtypes of gastric cancer. Nat. Genet. 2011, 43, 1219-1223.

95. Zang, Z.J.; Cutcutache, I.; Poon, S.L.; Zhang, S.L.; McPherson, J.R.; Tao, J.; Rajasegaran, V.; Heng, H.L.; Deng, N.; Gan, A.; et al. Exome sequencing of gastric adenocarcinoma identifies recurrent somatic mutations in cell adhesion and chromatin remodeling genes. Nat. Genet. 2012, 44, 570-574.

96. Abe, H.; Maeda, D.; Hino, R.; Otake, Y.; Isogai, M.; Ushiku, A.S.; Matsusaka, K.; Kunita, A.; Ushiku, T.; Uozaki, H.; et al. Arid1a expression loss in gastric cancer: Pathway-dependent roles with and without epstein-barr virus infection and microsatellite instability. Virchows Arch. 2012, 461, 367-377. 
97. Guichard, C.; Amaddeo, G.; Imbeaud, S.; Ladeiro, Y.; Pelletier, L.; Maad, I.B.; Calderaro, J.; Bioulac-Sage, P.; Letexier, M.; Degos, F.; et al. Integrated analysis of somatic mutations and focal copy-number changes identifies key genes and pathways in hepatocellular carcinoma. Nat. Genet. 2012, 44, 694-698.

98. Fujimoto, A.; Totoki, Y.; Abe, T.; Boroevich, K.A.; Hosoda, F.; Nguyen, H.H.; Aoki, M.; Hosono, N.; Kubo, M.; Miya, F.; et al. Whole-genome sequencing of liver cancers identifies etiological influences on mutation patterns and recurrent mutations in chromatin regulators. Nat. Genet. 2012, 44, 760-764.

99. Huang, J.; Deng, Q.; Wang, Q.; Li, K.Y.; Dai, J.H.; Li, N.; Zhu, Z.D.; Zhou, B.; Liu, X.Y.; Liu, R.F.; et al. Exome sequencing of hepatitis B virus-associated hepatocellular carcinoma. Nat. Genet. 2012, 44, 1117-1121.

100. Mamo, A.; Cavallone, L.; Tuzmen, S.; Chabot, C.; Ferrario, C.; Hassan, S.; Edgren, H.; Kallioniemi, O.; Aleynikova, O.; Przybytkowski, E.; et al. An integrated genomic approach identifies aridl $a$ as a candidate tumor-suppressor gene in breast cancer. Oncogene 2012, 31, 2090-2100.

101. Jones, S.; Li, M.; Parsons, D.W.; Zhang, X.; Wesseling, J.; Kristel, P.; Schmidt, M.K.; Markowitz, S.; Yan, H.; Bigner, D.; et al. Somatic mutations in the chromatin remodeling gene aridla occur in several tumor types. Hum. Mutat. 2012, 33, 100-103.

102. Maeda, D.; Mao, T.L.; Fukayama, M.; Nakagawa, S.; Yano, T.; Taketani, Y.; Shih, I.M. Clinicopathological significance of loss of aridla immunoreactivity in ovarian clear cell carcinoma. Int. J. Mol. Sci. 2010, 11, 5120-5128.

103. Katagiri, A.; Nakayama, K.; Rahman, M.T.; Rahman, M.; Katagiri, H.; Nakayama, N.; Ishikawa, M.; Ishibashi, T.; Iida, K.; Kobayashi, H.; et al. Loss of aridla expression is related to shorter progression-free survival and chemoresistance in ovarian clear cell carcinoma. Mod. Pathol. 2012, 25, 282-288.

104. Yamamoto, S.; Tsuda, H.; Takano, M.; Tamai, S.; Matsubara, O. Loss of arid1a protein expression occurs as an early event in ovarian clear-cell carcinoma development and frequently coexists with pik3ca mutations. Mod. Pathol. 2012, 25, 615-624.

105. Lowery, W.J.; Schildkraut, J.M.; Akushevich, L.; Bentley, R.; Marks, J.R.; Huntsman, D.; Berchuck, A. Loss of aridla-associated protein expression is a frequent event in clear cell and endometrioid ovarian cancers. Int. J. Gynecol. Cancer 2012, 22, 9-14.

106. Yamamoto, S.; Tsuda, H.; Takano, M.; Tamai, S.; Matsubara, O. Pik3ca mutations and loss of aridla protein expression are early events in the development of cystic ovarian clear cell adenocarcinoma. Virchows Arch. 2012, 460, 77-87.

107. Xiao, W.; Awadallah, A.; Xin, W. Loss of arid1a/baf250a expression in ovarian endometriosis and clear cell carcinoma. Int. J. Clin. Exp. Pathol. 2012, 5, 642-650.

108. Samartzis, E.P.; Samartzis, N.; Noske, A.; Fedier, A.; Caduff, R.; Dedes, K.J.; Fink, D.; Imesch, P. Loss of arid1a/baf250a-expression in endometriosis: A biomarker for risk of carcinogenic transformation? Mod. Pathol. 2012, 25, 885-892.

109. Ayhan, A.; Mao, T.L.; Seckin, T.; Wu, C.H.; Guan, B.; Ogawa, H.; Futagami, M.; Mizukami, H.; Yokoyama, Y.; Kurman, R.J.; et al. Loss of arid1a expression is an early molecular event in tumor progression from ovarian endometriotic cyst to clear cell and endometrioid carcinoma. Int. J. Gynecol. Cancer 2012, 22, 1310-1315. 
110. Bosse, T.; Ter Haar, N.T.; Seeber, L.M.; Diest, P.J.; Hes, F.J.; Vasen, H.F.; Nout, R.A.; Creutzberg, C.L.; Morreau, H.; Smit, V.T. Loss of aridla expression and its relationship with pi3k-akt pathway alterations, tp53 and microsatellite instability in endometrial cancer. Mod. Pathol. 2013, doi:10.1038/modpathol.2013.1096.

111. Han, G.; Sidhu, D.; Duggan, M.A.; Arseneau, J.; Cesari, M.; Clement, P.B.; Ewanowich, C.A.; Kalloger, S.E.; Kobel, M. Reproducibility of histological cell type in high-grade endometrial carcinoma. Mod. Pathol. 2013, doi:10.1038/modpathol.2013.1102.

112. Allo, G.; Bernardini, M.Q.; Wu, R.C.; Shih, I.M.; Kalloger, S.; Pollett, A.; Gilks, C.B.; Clarke, B.A. Arid1a loss correlates with mismatch repair deficiency and intact p53 expression in high-grade endometrial carcinomas. Mod. Pathol. 2013, doi:10.1038/modpathol.2013.1144.

113. Engelman, J.A. Targeting pi3k signalling in cancer: Opportunities, challenges and limitations. Nat. Rev. Cancer 2009, 9, 550-562.

114. Liu, P.; Cheng, H.; Roberts, T.M.; Zhao, J.J. Targeting the phosphoinositide 3-kinase pathway in cancer. Nat. Rev. Drug Discov. 2009, 8, 627-644.

115. Wullschleger, S.; Loewith, R.; Hall, M.N. Tor signaling in growth and metabolism. Cell 2006, $124,471-484$.

116. Yin, X.; Pavone, M.E.; Lu, Z.; Wei, J.; Kim, J.J. Increased activation of the pi3k/akt pathway compromises decidualization of stromal cells from endometriosis. J. Clin. Endocrinol. Metab. 2012, 97, E35-E43.

117. Honda, H.; Barrueto, F.F.; Gogusev, J.; Im, D.D.; Morin, P.J. Serial analysis of gene expression reveals differential expression between endometriosis and normal endometrium. Possible roles for axl and shc1 in the pathogenesis of endometriosis. Reprod. Biol. Endocrinol. 2008, 6, 59.

118. Zhang, H.; Zhao, X.; Liu, S.; Li, J.; Wen, Z.; Li, M. 17 betae2 promotes cell proliferation in endometriosis by decreasing pten via nfkappab-dependent pathway. Mol. Cell. Endocrinol. 2010, 317, 31-43.

119. Laudanski, P.; Szamatowicz, J.; Kowalczuk, O.; Kuzmicki, M.; Grabowicz, M.; Chyczewski, L. Expression of selected tumor suppressor and oncogenes in endometrium of women with endometriosis. Hum. Reprod. 2009, 24, 1880-1890.

120. Li, M.Q.; Luo, X.Z.; Meng, Y.H.; Mei, J.; Zhu, X.Y.; Jin, L.P.; Li, D.J. Cxcl8 enhances proliferation and growth and reduces apoptosis in endometrial stromal cells in an autocrine manner via a cxcr1-triggered pten/akt signal pathway. Hum. Reprod. 2012, 27, 2107-2116.

121. Zhang, H.; Li, M.; Zheng, X.; Sun, Y.; Wen, Z.; Zhao, X. Endometriotic stromal cells lose the ability to regulate cell-survival signaling in endometrial epithelial cells in vitro. Mol. Hum. Reprod. 2009, 15, 653-663.

122. Matsuzaki, S.; Canis, M.; Vaurs-Barriere, C.; Boespflug-Tanguy, O.; Dastugue, B.; Mage, G. Dna microarray analysis of gene expression in eutopic endometrium from patients with deep endometriosis using laser capture microdissection. Fertil. Steril. 2005, 84, S1180-S1190.

123. Grund, E.M.; Kagan, D.; Tran, C.A.; Zeitvogel, A.; Starzinski-Powitz, A.; Nataraja, S.; Palmer, S.S. Tumor necrosis factor-alpha regulates inflammatory and mesenchymal responses via mitogen-activated protein kinase kinase, p38, and nuclear factor kappab in human endometriotic epithelial cells. Mol. Pharmacol. 2008, 73, 1394-1404. 
124. Klemmt, P.A.; Carver, J.G.; Kennedy, S.H.; Koninckx, P.R.; Mardon, H.J. Stromal cells from endometriotic lesions and endometrium from women with endometriosis have reduced decidualization capacity. Fertil. Steril. 2006, 85, 564-572.

125. Aghajanova, L.; Hamilton, A.; Kwintkiewicz, J.; Vo, K.C.; Giudice, L.C. Steroidogenic enzyme and key decidualization marker dysregulation in endometrial stromal cells from women with versus without endometriosis. Biol. Reprod. 2009, 80, 105-114.

126. Velarde, M.C.; Aghajanova, L.; Nezhat, C.R.; Giudice, L.C. Increased mitogen-activated protein kinase kinase/extracellularly regulated kinase activity in human endometrial stromal fibroblasts of women with endometriosis reduces 3',5'-cyclic adenosine 5'-monophosphate inhibition of cyclin d1. Endocrinology 2009, 150, 4701-4712.

127. Wynn, R.M. Ultrastructural development of the human decidua. Am. J. Obstet. Gynecol. 1974, $118,652-670$.

128. Feroze-Zaidi, F.; Fusi, L.; Takano, M.; Higham, J.; Salker, M.S.; Goto, T.; Edassery, S.; Klingel, K.; Boini, K.M.; Palmada, M.; et al. Role and regulation of the serum- and glucocorticoid-regulated kinase 1 in fertile and infertile human endometrium. Endocrinology 2007, 148, 5020-5029.

129. Labied, S.; Kajihara, T.; Madureira, P.A.; Fusi, L.; Jones, M.C.; Higham, J.M.; Varshochi, R.; Francis, J.M.; Zoumpoulidou, G.; Essafi, A.; et al. Progestins regulate the expression and activity of the forkhead transcription factor foxol in differentiating human endometrium. Mol. Endocrinol. 2006, 20, 35-44.

130. Kim, J.J.; Kurita, T.; Bulun, S.E. Progesterone action in endometrial cancer, endometriosis, uterine fibroids, and breast cancer. Endocr. Rev. 2013, 34, 130-162.

131. Banerjee, S.; Kaye, S.B. New strategies in the treatment of ovarian cancer: Current clinical perspectives and future potential. Clin. Cancer Res. 2013, 19, 961-968.

132. Kuo, K.T.; Mao, T.L.; Jones, S.; Veras, E.; Ayhan, A.; Wang, T.L.; Glas, R.; Slamon, D.; Velculescu, V.E.; Kuman, R.J.; et al. Frequent activating mutations of pik3ca in ovarian clear cell carcinoma. Am. J. Pathol. 2009, 174, 1597-1601.

133. Hashiguchi, Y.; Tsuda, H.; Inoue, T.; Berkowitz, R.S.; Mok, S.C. Pten expression in clear cell adenocarcinoma of the ovary. Gynecol. Oncol. 2006, 101, 71-75.

134. Tan, D.S.; Iravani, M.; McCluggage, W.G.; Lambros, M.B.; Milanezi, F.; Mackay, A.; Gourley, C.; Geyer, F.C.; Vatcheva, R.; Millar, J.; et al. Genomic analysis reveals the molecular heterogeneity of ovarian clear cell carcinomas. Clin. Cancer Res. 2011, 17, 1521-1534.

135. Carden, C.P.; Stewart, A.; Thavasu, P.; Kipps, E.; Pope, L.; Crespo, M.; Miranda, S.; Attard, G.; Garrett, M.D.; Clarke, P.A.; et al. The association of pi3 kinase signaling and chemoresistance in advanced ovarian cancer. Mol. Cancer Ther. 2012, 11, 1609-1617.

136. Tan, D.S.; Miller, R.E.; Kaye, S.B. New perspectives on molecular targeted therapy in ovarian clear cell carcinoma. Br. J. Cancer 2013, 108, 1553-1559.

137. Yamamoto, S.; Tsuda, H.; Takano, M.; Iwaya, K.; Tamai, S.; Matsubara, O. Pik3ca mutation is an early event in the development of endometriosis-associated ovarian clear cell adenocarcinoma. J. Pathol. 2011, 225, 189-194.

138. Campbell, I.G.; Russell, S.E.; Choong, D.Y.; Montgomery, K.G.; Ciavarella, M.L.; Hooi, C.S.; Cristiano, B.E.; Pearson, R.B.; Phillips, W.A. Mutation of the pik3ca gene in ovarian and breast cancer. Cancer Res. 2004, 64, 7678-7681. 
139. Wang, Y.; Helland, A.; Holm, R.; Kristensen, G.B.; Borresen-Dale, A.L. Pik3ca mutations in advanced ovarian carcinomas. Hum. Mutat. 2005, 25, 322.

140. Levine, D.A.; Bogomolniy, F.; Yee, C.J.; Lash, A.; Barakat, R.R.; Borgen, P.I.; Boyd, J. Frequent mutation of the pik3ca gene in ovarian and breast cancers. Clin. Cancer Res. 2005, 11, 2875-2878.

141. Willner, J.; Wurz, K.; Allison, K.H.; Galic, V.; Garcia, R.L.; Goff, B.A.; Swisher, E.M. Alternate molecular genetic pathways in ovarian carcinomas of common histological types. Hum. Pathol. 2007, 38, 607-613.

142. Rahman, M.; Nakayama, K.; Rahman, M.T.; Nakayama, N.; Ishikawa, M.; Katagiri, A.; Iida, K.; Nakayama, S.; Otsuki, Y.; Shih, I.M.; et al. Clinicopathologic and biological analysis of pik3ca mutation in ovarian clear cell carcinoma. Hum. Pathol. 2012, 43, 2197-2206.

143. McConechy, M.K.; Ding, J.; Senz, J.; Yang, W.; Melnyk, N.; Tone, A.A.; Prentice, L.M.; Wiegand, K.C.; McAlpine, J.N.; Shah, S.P.; et al. Ovarian and endometrial endometrioid carcinomas have distinct ctnnb1 and pten mutation profiles. Mod. Pathol. 2013, doi:10.1038/modpathol.2013.1107.

144. Vestergaard, A.L.; Thorup, K.; Knudsen, U.B.; Munk, T.; Rosbach, H.; Poulsen, J.B.; Guldberg, P.; Martensen, P.M. Oncogenic events associated with endometrial and ovarian cancers are rare in endometriosis. Mol. Hum. Reprod. 2011, 17, 758-761.

145. Janku, F.; Wheler, J.J.; Westin, S.N.; Moulder, S.L.; Naing, A.; Tsimberidou, A.M.; Fu, S.; Falchook, G.S.; Hong, D.S.; Garrido-Laguna, I.; et al. Pi3k/akt/mtor inhibitors in patients with breast and gynecologic malignancies harboring pik3ca mutations. J. Clin. Oncol. 2012, 30, 777-782.

146. Church, D.; Koppensteiner, R.; Yap, T.; Fink, D.; Dedes, K. Pi3k-akt-mtor inhibitors for the systematic treatment of endometrial cancer. Expert Rev. Obstet. Gynecol. 2012, 5, 421-430.

147. Yap, T.A.; Carden, C.P.; Kaye, S.B. Beyond chemotherapy: Targeted therapies in ovarian cancer. Nat. Rev. Cancer 2009, 9, 167-181.

148. Mabuchi, S.; Kawase, C.; Altomare, D.A.; Morishige, K.; Sawada, K.; Hayashi, M.; Tsujimoto, M.; Yamoto, M.; Klein-Szanto, A.J.; Schilder, R.J.; et al. Mtor is a promising therapeutic target both in cisplatin-sensitive and cisplatin-resistant clear cell carcinoma of the ovary. Clin. Cancer Res. 2009, 15, 5404-5413.

149. Verhaak, R.G.; Tamayo, P.; Yang, J.Y.; Hubbard, D.; Zhang, H.; Creighton, C.J.; Fereday, S.; Lawrence, M.; Carter, S.L.; Mermel, C.H.; et al. Prognostically relevant gene signatures of high-grade serous ovarian carcinoma. J. Clin. Invest. 2013, 123, 517-525.

150. Mabuchi, S.; Altomare, D.A.; Cheung, M.; Zhang, L.; Poulikakos, P.I.; Hensley, H.H.; Schilder, R.J.; Ozols, R.F.; Testa, J.R. Rad001 inhibits human ovarian cancer cell proliferation, enhances cisplatin-induced apoptosis, and prolongs survival in an ovarian cancer model. Clin. Cancer Res. 2007, 13, 4261-4270.

151. Di Nicolantonio, F.; Arena, S.; Tabernero, J.; Grosso, S.; Molinari, F.; Macarulla, T.; Russo, M.; Cancelliere, C.; Zecchin, D.; Mazzucchelli, L.; et al. Deregulation of the pi3k and kras signaling pathways in human cancer cells determines their response to everolimus. J. Clin. Invest. 2010, 120, 2858-2866. 
152. Ihle, N.T.; Lemos, R.; Wipf, P.; Yacoub, A.; Mitchell, C.; Siwak, D.; Mills, G.B.; Dent, P.; Kirkpatrick, D.L.; Powis, G. Mutations in the phosphatidylinositol-3-kinase pathway predict for antitumor activity of the inhibitor px-866 whereas oncogenic ras is a dominant predictor for resistance. Cancer Res. 2009, 69, 143-150.

153. Shimizu, T.; Tolcher, A.W.; Papadopoulos, K.P.; Beeram, M.; Rasco, D.W.; Smith, L.S.; Gunn, S.; Smetzer, L.; Mays, T.A.; Kaiser, B.; et al. The clinical effect of the dual-targeting strategy involving pi3k/akt/mtor and ras/mek/erk pathways in patients with advanced cancer. Clin. Cancer Res. 2012, 18, 2316-2325.

154. Gao, X.; Tate, P.; Hu, P.; Tjian, R.; Skarnes, W.C.; Wang, Z. Es cell pluripotency and germ-layer formation require the swi/snf chromatin remodeling component baf250a. Proc. Natl. Acad. Sci. USA 2008, 105, 6656-6661.

155. Luo, B.; Cheung, H.W.; Subramanian, A.; Sharifnia, T.; Okamoto, M.; Yang, X.; Hinkle, G.; Boehm, J.S.; Beroukhim, R.; Weir, B.A.; et al. Highly parallel identification of essential genes in cancer cells. Proc. Natl. Acad. Sci. USA 2008, 105, 20380-20385.

156. Nagl, N.G.; Wang, X.; Patsialou, A.; van Scoy, M.; Moran, E. Distinct mammalian swi/snf chromatin remodeling complexes with opposing roles in cell-cycle control. EMBO J. 2007, 26, 752-763.

157. Nagl, N.G.; Patsialou, A.; Haines, D.S.; Dallas, P.B.; Beck, G.R.; Moran, E. The p270 (arid1a/smarcf1) subunit of mammalian swi/snf-related complexes is essential for normal cell cycle arrest. Cancer Res. 2005, 65, 9236-9244.

158. Zhang, X.; Zhang, Y.; Yang, Y.; Niu, M.; Sun, S.; Ji, H.; Ma, Y.; Yao, G.; Jiang, Y.; Shan, M.; et al. Frequent low expression of chromatin remodeling gene aridla in breast cancer and its clinical significance. Cancer Epidemiol. 2012, 36, 288-293.

159. Liang, H.; Cheung, L.W.; Li, J.; Ju, Z.; Yu, S.; Stemke-Hale, K.; Dogruluk, T.; Lu, Y.; Liu, X.; $\mathrm{Gu}, \mathrm{C}$; et al. Whole-exome sequencing combined with functional genomics reveals novel candidate driver cancer genes in endometrial cancer. Genome Res. 2012, 22, 2120-2129.

160. Darr, J.; Klochendler, A.; Isaac, S.; Eden, A. Loss of igfbp7 expression and persistent akt activation contribute to smarcb1/snf5-mediated tumorigenesis. Oncogene 2013, doi:10.1038/onc.2013.261.

161. Guan, B.; Wang, T.L.; Shih, I.M. In Aridla Loss in Collaboration with pi3k Pathway Activation Leads to Ovarian Tumorigenesis in Mouse, Proceedings of the 104th Annual Meeting of the American Association for Cancer Research, Washington, DC, USA, 6-10 April 2013; Walter, E., Ed.; AACR: Philadelphia, PA, USA, 2013; LB-259.

162. Gui, Y.; Guo, G.; Huang, Y.; Hu, X.; Tang, A.; Gao, S.; Wu, R.; Chen, C.; Li, X.; Zhou, L.; et al. Frequent mutations of chromatin remodeling genes in transitional cell carcinoma of the bladder. Nat. Genet. 2011, 43, 875-878.

163. Fadare, O.; Renshaw, I.L.; Liang, S.X. Does the loss of arid1a (baf-250a) expression in endometrial clear cell carcinomas have any clinicopathologic significance? A pilot assessment. J. Cancer 2012, 3, 129-136.

(C) 2013 by the authors; licensee MDPI, Basel, Switzerland. This article is an open access article distributed under the terms and conditions of the Creative Commons Attribution license (http://creativecommons.org/licenses/by/3.0/). 